Southern Methodist University

SMU Scholar

Faculty Journal Articles and Book Chapters

Faculty Scholarship

2002

\title{
Fast, Cheap \& Out of Control: Lessons from the Icann Dispute Resolution Process
}

Elizabeth G. Thornburg

Southern Methodist University, Dedman School of Law

Recommended Citation

Elizabeth G. Thornburg, Fast, Cheap, and out of Control: Lessons from the ICANN Dispute Resolution Process, 6 J. Small \& Emerging Bus. L. 191 (2002)

This document is brought to you for free and open access by the Faculty Scholarship at SMU Scholar. It has been accepted for inclusion in Faculty Journal Articles and Book Chapters by an authorized administrator of SMU Scholar. For more information, please visit http://digitalrepository.smu.edu. 


\title{
FAST, CHEAP, AND OUT OF CONTROL: \\ LESSONS FROM THE ICANN DISPUTE RESOLUTION PROCESS
}

\author{
by \\ Elizabeth G. Thomburg*
}

\begin{abstract}
In this Article, Professor Thornburg addresses certain multijurisdictional dispute resolution issues arising out of the expansion of the Internet. She notes that national court systems are ill equipped to handle some of these international quandaries because of differences in substantive and procedural law. Significant enforcement problems also arise in multijurisdictional disputes. Privatized Online Dispute Resolution (ODR) provides an alternative to national court systems. Professor Thornburg analyzes whether the Uniform Dispute Resolution Policy (UDRP) of the Internet Corporation for Assigned Names and Numbers (ICANN) provides a good model of global ODR. She begins by describing the development of the UDRP. She then discusses the system's qualities and the problems revealed by the operation of the ICANN process. Professor Thornburg asserts that the UDRP makes a few good procedural choices, but is nevertheless a flawed system that does not operate fairly even within its own limited sphere. Finally, Professor Thornburg explores the lessons of the UDRP, and concludes that a just and equitable system would share few qualities with the UDRP.
\end{abstract}

I. INTRODUCTION: DEALING WITH UNCERTAINTY....... 192

II. ICANN AND THE UDRP....................... 196

III. SUCCESSES: WHAT ICANN DOES RIGHT ............ 203

IV. FAILURES: PROBLEMS OF LEGITIMACY AND FAIRNESS .. 207

A. Lessons About Creating Law...................... 208

B. Lessons About Creating Procedures ................. 213

1. Forum Shopping ......................... 214

2. Mandatory Participation ..................... 214

3. Slanted Procedural Rules..................... 215

4. No Mechanism for Information Sharing ............ 216

* Professor, Dedman School of Law, Southern Methodist University. () Elizabeth G. Thornburg. This article was prepared for the Seventh Annual Lewis \& Clark Law Forum, Deciding ICANN Domain Name Disputes: Questioning Delegation, Fairness, and Consent, Oct. 5, 2001. It was also supported by the Faculty Excellence Endowment of the Dedman School of Law. I would like to thank Michael Froomkin, Jean Sternlight, Manon Ress, Graeme Dinwoodie, and the participants in the Forum for their helpful comments on earlier drafts of this article. 


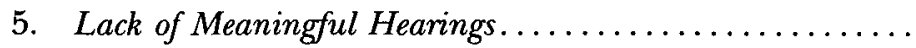

6. Unimaginative Use of Technology and ADR Methods......

7. Decisionmaker Bias .............................

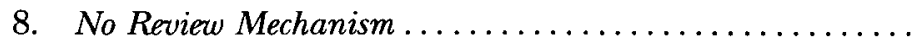

VI. CONCLUSION ...............................

\section{INTRODUCTION: DEALING WITH UNCERTAINTY}

The Internet is constantly expanding, both as a means of communication $^{1}$ and as a means of commerce. ${ }^{2}$ As its contacts among people and businesses expand, more and more disputes will arise and will need resolution. ${ }^{3}$ These disputes will evolve out of relationships such as business to consumer transactions and business to business transactions and may be contract disputes, breach of warranty claims, or even allegations of fraud. Others will be disagreements about intellectual property rights such as trademarks, copyrights, and patents. Some will involve competition law, raising issues of antitrust, trade disparagement, or other claims of unfair competition. Disputes will also arise over more personal rights, including claims of defamation, invasion of privacy, emotional distress, or even personal injury claims stemming from products sold on the Internet. The global reach of the Internet and of modern business also makes it likely that a substantial number of these disputes will involve persons or entities in different states and countries, some very distant and legally different from each other. ${ }^{4}$

Many of these multijurisdictional disputes raise exactly the kinds of issues typically found in U.S. litigation involving citizens of more than one state, such as differences in substantive law, procedural rules, and

1 For example, the number of Internet users in the People's Republic of China has risen from about four million at the beginning of 2000 to more than 30 million, thanks largely to the number of cyber-cafes opening around the country. Gregg Jones, By Bits, Web Use Eroding China's Formidable Control, Dallas Morning News, Aug. 6, 2001 , at $1 \mathrm{~A}$.

2 The number of "small" merchants (those with annual sales from $\$ 100,000$ to $\$ 10$ million) on the Internet is projected to increase from 17,500 in 1999 to 2.6 million in 2004. Alan Wiener, Opportunities and Initiatives in Online Dispute Resolution, 24 SPIDR News, Summer 2000, at 2, http://www. mediate.com/articles/awiener1.cfm (newsletter of the Society of Professionals in Dispute Resolution).

3 The New York Attorney General's office reported twice as many complaints about Internet shopping in 1999 as in 1998. Joseph P. Fried, Internet Complaints Are Climbing in New York, Spitzer Says, N.Y. Trmes, Nov. 2, 2000, at B8. Similarly, the Council of Better Business Bureaus reported twice as many consumer complaints against online retailers in 2000 as in 1999. Joanna Glasner, Net Shoppers Still Complaining, WIRED, June 11, 2001, at 1, at http://www.wired.com/news.

${ }^{4}$ Cf. William W. Woodward, Jr., Contractual Choice of Law: Legislative Choice in an Era of Party Autonomy, 54 S.M.U. L. REv. 697, 747 (2001) ("Increasingly, our goods and services are coming through distribution mechanisms that originate abroad and have at least one international contact within the chain of distribution."). 
choice of law rules. As the disputes move from interstate to international, the differences and practical difficulties increase. Differences in substantive law may be more substantial, differences in procedural rules more significant, differences in the ability to acquire jurisdiction more diverse, and differences in choice of law rules more complex..$^{5}$ Also, multinational disputes can add a layer of enforcement difficulties. If a defendant does not have assets in the original forum to satisfy the judgment, the prevailing party must take any resulting judgment to the defendant/judgment debtor's home country to seek enforcement. ${ }^{6}$ If the amount in controversy between the parties is comparatively small, ${ }^{7}$ the cost of resolving these legal issues may, as a practical matter, prevent the claimant from pursuing redress.

Some potential solutions to these international quandaries deal with the legal differences head on. One solution would be to harmonize substantive law, so that all countries (or at least those likely to have frequent Internet contacts) adopt the same rules governing primary behavior, whether it be consumer transactions, products liability, defamation, intellectual property, or competition law. ${ }^{8}$ Another option would be negotiat-

5 Alejandro E. Almaguer \& Roland W. Baggott III, Shaping New Legal Frontiers: Dispute Resolution for the Internet, 13 OHIo ST. J. Disp. Resol. 711, 711 (1997) (identifying personal jurisdiction and choice of law issues as obstacles to resolving Internet disputes); Bureau of Consumer Protection, federal Trade Commission, Consumer Protection in the Global Electronic Marketplace: looking Ahead 4-15, (Sept. 2000), http://www.ftc.gov/bcp/icpw/lookingahead/electronicmkpl.pdf (discussing choice of law problems).

${ }^{6}$ More accurately, the prevailing plaintiff would need to take the judgment to a jurisdiction in which the defendant does have assets. Unlike the enforcement of judgments between sister states, no Full Faith and Credit Clause compels enforcement of a foreign country judgment. For a helpful discussion of the difficulties one might encounter enforcing a U.S. money judgment in the courts of various U.S. trading partners, see Committee on Foreign and Comparative Law, Association of the Bar of the City of New York, Survey on Foreign Recognition of U.S. Money Judgments, 56 RECoRD 378, 410 (Summer 2001) (concluding that "the recognition of [U.S. money judgments] abroad is subject to inconsistent legal regimes and a myriad of substantive, procedural, and practical hurdles") (survey prepared at request of the State Department to aid in its negotiations of the proposed Hague Convention on Jurisdiction and Foreign Judgments in Civil and Commercial Matters).

7 One source estimates the median amount of all online transactions as just $\$ 300$. The median business-to-business ("B2B") transaction is $\$ 800$, and more than half are under $\$ 1,000$. The median business-to-consumer (“B2C") transaction is $\$ 244$, and $37 \%$ are less than $\$ 100$. Wiener, supra note 2 , http://www.mediate.com/articles/ awiener1.cfm.

8 See A. Michael Froomkin, Of Governments and Governance, 14 Berkeley TeCH. L.J. 617,623 (1999) [hereinafter Froomkin on Governance] (discussing various ways global law could be harmonized); see also Pamela Samuelson, Five Challenges for Regulating the Information Society, in Regulating The Global Information Society 316, 323 (Christopher T. Marsden ed., 2000) ("As desirable as complete harmonization of laws may seem in the abstract, achieving harmonization is likely to be a tediously slow process."). 
ing international treaties agreeing on substantive law that would apply only to Internet disputes, although distinguishing between Internet activities and their "real world" impacts is difficult if not fictional. If countries cannot harmonize their laws to this extent, which seems likely as some of the legal differences reflect deeply-held policy disagreements, ${ }^{9}$ an alternative would be the negotiation of international treaties concerning jurisdiction and judgment. Everyone would agree about personal jurisdiction, choice of law, and the enforcement of other countries' judgments. ${ }^{10}$

No one believes that any of that will happen, especially not within the next few years. The resulting uncertainty leaves Internet sellers and consumers, joint venture partners and competitors, the criticized and the critics, and owners and users of intellectual property in a state of inevitable risk. When disputes arise out of Internet activity, there is no way to know with certainty what law will apply and in what forum. ${ }^{11}$ What's an Internet user to do? Enter privatized online dispute resolution ("ODR") systems, an alternative to using national courts (and sometimes national

9 Even in the comparatively harmonized area of contracts of sale, for example, within the European Union (unlike in many U.S. states) sellers of new consumer goods may not insert enforceable waivers of consumer rights into their contracts. See Thomas Krümmel \& Rose M. D'Sa, Sales of Consumer Goods and Associated Guarantees: A Minimalist Approach to Harmonised European Union Consumer Protection, 26 EUR. L. REV. 312 (2001) (discussing Council Directive 1999/44, 1999 O.J. (L171) 12). Similarly, many countries refuse to enforce predispute binding arbitration clauses. See Consumer affairs Division, Department of the Treasury, Commonwealth of Australia, Dispute Resolution in Electronic Commerce: Discussion Paper 22-25 (Oct. 2001), http://www.ecommerce.treasury gov.au (discussing international policy context).

10 Given the debates raging over the proposed Hague Convention on Jurisdiction and the Recognition and Enforcement of Foreign Judgments in Civil and Commercial Matters, which seeks to do exactly this, it is highly unlikely that a comprehensive agreement will be forthcoming anytime soon. See Anandashankar Mazumdar, New Hague Draft Reflects Influence of Electronic Commerce Interests on Process, 6 Electronic Com. \& L. Rep. (BNA) 830 (Aug. 8, 2001), available at http:// pubs.bna.com/ip/bna/eip.nsf (reporting that the June negotiating session resulted in a version that is "longer and less finalized than the version issued almost two years ago"). See also Jean Eaglesham \& Patti Waldemeir, Laws Unto Themselves, Financial Times, July 9, 2001, at 22 (reporting that the June meetings achieved little but an agreement to resume discussions by 2003 , chiefly because of "a fundamental difference of approach between the US and the EU"). The current draft of the proposed Convention is available at http://pub.bna.com/eclr/Hague20010802.pdf. Texts of previous drafts, as well as related information, are available at the web site of the Hague Conference on Private International Law, http://www.hcch.net. Presently, it appears that the most optimistic outlook for the proposed Convention would be some kind of scaled back version, covering some transactions (such as B2B contracts), but not others.

11 Some try to minimize the uncertainty through contractually imposed predispute mandatory binding arbitration clauses, creating their own nonappealable procedures and their own "law." These clauses will not always be enforced in the countries in which aggrieved contracting parties might file suit. They also have no role to play in disputes between persons without a contractual relationship unless a third party has the power to impose arbitration. 
law) that is allegedly faster, cheaper, and more convenient for everyone involved. ${ }^{12}$ Ideally, the design and implementation of ODR systems could be a unique opportunity to create fair and accessible processes that would accurately and evenhandedly resolve individual disputes and assure the enforcement of important national laws and policies. ${ }^{13}$ Unfortunately, ODR systems could also become one more way for "repeat players" 14 to replicate their societal advantages, this time on a global level and largely free of public scrutiny. ${ }^{15}$ Thus the context and structure of the systems that evolve will be crucially important in ensuring procedural fairness and the rule of law.

Some suggest that the Uniform Dispute Resolution Policy ("UDRP") ${ }^{16}$ currently used by the Internet Corporation for Assigned Names and Numbers ("ICANN") to resolve Internet domain name disputes is a good model for global ODR. ${ }^{17}$ This article, however, argues

12 Businesses providing ODR of one kind or another are proliferating. Wendy $\mathrm{R}$. Leibowitz, Let's Settle This, Online, NAT'L L.J., July 5, 1999, at A20; Wiener, supra note 2, http://www.mediate.com/articles/ awienerl.cfm.

13 See Burfau of Consumer Protection, supra note 5, at 11-12, http:// www.ftc.gov/bcp/icpw/lookingahead/electronicmkpl.pdf (recommending the development of ADR systems for e-commerce because "ADR can be a practical way to provide consumers with fast, inexpensive, and effective remedies, and can reduce businesses' exposure to foreign litigation"); Recommendation of the OECD Council Concerning Guidelines for Consumer Protection in the Context of Electronic Commerce (Dec. 9, 1999), http://www.ftc.gov/opa/1999/9912/oecdguide.htm.

14 Marc Galanter, Why the "Haves" Come Out Ahead: Speculations on the Limits of Legal Change, 9 Law \& Soc'y Rev. 95 (1974).

15 See Carrie Menkel-Meadow, Do the "Haves" Come Out Ahead in Alternative Judicial Systems?: Repeat Players in ADR, 15 OHIO ST. J. DisP. Resol. 19, 25-26 (1999) ("To put it simply, the "Haves" come out ahead by being able to choose and manipulate what process will be used to enforce substantive rights. . . [T] he question of whether power recapitulates itself in all forms of dispute systems is clearly ripe."); Jean $\mathbf{R}$. Sternlight, Panacea or Corporate Tool?: Debunking the Supreme Court's Preference for Binding Arbitration, 74 WASH. U. L.Q. 637, 681 (1996)

(Few would deny that consumers would benefit from a quicker, cheaper system of justice, all else being equal. However, all else is not equal. The truth is that businesses opt for arbitration not only to reduce transaction costs that may or may not accrue equally to consumers, but also to reduce their payouts.);

Llewellyn Joseph Gibbons, Rusticum Judicium? Private "Courts" Enforcing Private Law and Rights: Regulating Virtual Arbitration in Cyberspace, 24 Oнго N.U. L. Rev. 769, 774 (1998).

16 ICANN, Uniform Domain Name Dispute Resolution Policy (Aug. 26, 1999), at http://www.icann.org/udrp/udrp-policy-24oct99.htm [hereinafter UDRP]; ICANN, Rules for Uniform Domain Name Dispute Resolution Policy (Oct. 24, 1999), at http://www.icann.org/udrp/udrp-rules-24oct99.htm [hereinafter ICANN RuLEs].

17 See Victoria Carrington, Internet Needs Fast, Fair Dispute Resolution Process, 20 L.aws. WkLY, Nov. 17, 2000; House Subcommittee Explores Internet Jurisdiction Issues, 1 INTERNET L. \& Bus. 822, 824 (2000) (reporting testimony before House Judiciary Committee's Subcommittee on Courts and Intellectual Property that supported private sector codes of conduct for consumer ADR); David McGuire, US Must Demand Strong Dispute Framework-Industry, NewsBYTES, June 29, 2000, at http:// 
that although the UDRP makes a few good procedural choices, it is a flawed system that does not operate fairly even within its own limited sphere. Its failures provide some sobering reminders of the potential weaknesses of privatized dispute resolution systems. Section II of this article briefly describes the development of the UDRP and the way it works. Section III discusses the system's more positive qualities, while Section IV focuses on the problems revealed by the operation to date of the ICANN process. Section V explores the lessons of the UDRP broadly, and section VI concludes that a just and equitable system would share few qualities with the UDRP.

\section{ICANN AND THE UDRP}

The Internet's domain name system is currently (since 1998) administered by ICANN, a private, not-for-profit corporation, under the authority of a series of understandings with the U.S. Department of Commerce. ${ }^{18}$ One of ICANN's first assignments was to adopt a dispute resolution policy to allow speedy and inexpensive resolution of conflicts regarding rights to domain names. ICANN approved its Uniform Domain Name Dispute Resolution Policy (UDRP) ${ }^{19}$ and Rules for Uniform Domain Name Dispute Resolution Policy ${ }^{20}$ on October 24, 1999, and they went into effect on December 1, 1999. ICANN imposes this policy on

www.newsbytes.com/news/00/151438.html (quoting Mark Thurman of the American Intellectual Property Law Association, who claimed the UDRP would "serve as a good template for a broader dispute resolution apparatus"); Thomas $\mathrm{H}$. Webster, Domain Name Proceedings and International Dispute Resolution, 2001 Bus. L. INT'L 215; Tim Cole, ICANN Domain Name Dispute Policy-Year One, Metropolitan Corp. Couns., Feb. 2001, at 31 (reporting that Assistant Director of National Arbitration Forum applauds UDRP as "a model of dispute resolution for the 21st century").

18 See ICANN, Approved Agreements Among ICANN, the U.S. Department of Commerce, AND NeTwork Solutions, Inc., at http://www.icann.org.nsi/ nsiagreements.htm (posted Nov. 10, 1999). ICANN is pronounced EYE-can, as in "I can at least try to manage the Internet." Whatis?com, at http:// www.whatis.techtarget.com (last updated Apr. 27, 2001). In a sense, ICANN is the successor to the Internet Assigned Numbers Authority (IANA), which derived its authority under a contract from the U.S. government which financed the original research network, ARPANET, from which the Internet grew. The need to internationalize the governing of the Internet led the U.S. government to recommend the origin of ICANN as a global, nongovernmental entity. Id. For a fuller account of the transfer of authority to ICANN, see A. Michael Froomkin, Wrong Turn in Cyberspace: Using ICANN to Route Around the APA and the Constitution, 50 Duke L.J. 17 (2000) [hereinafter Froomkin Wrong Turn]; Laura Pearlman, Truth, Justice and the Dot-Com Wars, Law News Network, Mar. 31 2000, at http:// www.lawnewsnetwork.com/practice/techlaw/news.

19 UDRP, supra note 16. For a thorough discussion of the evolution of proposals to create a dispute resolution system for domain names through the adoption of the ICANN Policy and ICANN Rules, see Laurence R. Helfer \& Graeme B. Dinwoodie, Designing Non-National Systems: The Case of the Uniform Domain Name Dispute Resolution Policy, 43 WM. \& MaRY L. Rev. 141, 144-54 (2001).

20 ICANN Rules, supra note 16. 
approved domain name registrars, and through them onto all who acquire domain names. ${ }^{21}$

One can see the superficial appeal of an ICANN-like process to resolve international Internet disputes. First, it applies globally; all disputes about top level domain names ending in .com, .net, and .org are subject to this policy, no matter where in the world the parties reside or do business and no matter where the domain name holder registered the domain. This eliminates the tricky issue of personal jurisdiction over the domain name holder. It also manages to create a contractually-mandated private system for the benefit of noncontracting parties. Second, because the process does not require (or even allow) personal appearances by the parties, ${ }^{22}$ it minimizes geographic distance problems. Parties need not travel to participate in the process. Third, the UDRP attempts to overcome the choice of law problems raised by differences in national trademark laws by creating its own "law" in the ICANN Policy. Finally, because ICANN has a contract with the company that controls the root server that assigns domain names, it has the power to enforce the arbitrators' decisions without the need to ask a court to enforce the judgment.

The ICANN Policy allows a trademark holder to submit a complaint to any dispute resolution provider (DRP) approved by ICANN. ${ }^{23}$ The complainant must allege and convince the arbitrator that:

1. the domain name is identical or confusingly similar to a trademark or service mark in which the complainant has rights; and

2. the domain name holder has no rights or legitimate interests in respect of the domain name; and

21 Registrars are companies, which are licensed by ICANN, that have the power to assign new domain names. Registrars must be accredited by ICANN, and they must agree to abide by ICANN's rules. See ICANN, REgISTRATION ACCREDITATION, at http:// www.icann.org/registrars/ accreditation-process.htm (page updated July 26, 2001). ICANN's rules require the registrars to incorporate the UDRP into the registration agreements between the registrar and the domain name holders. Paragraph 1 of the ICANN Policy informs domain name holders that the dispute resolution policy is "incorporated by reference into your Registration Agreement." UDRP, supra note 16, $\S 1$.

${ }^{22}$ Pleadings are filed in hard copy and electronically, and attachments are generally sent by mail.

23 There are currently four approved DRPs: 1) World Intellectual Property Organization (WIPO), 2) the National Arbitration Forum (NAF), 3) eResolution (eRes), and 4) CPR Institute for Dispute Resolution. See ICANN, ApProved Providers For Uniform Domain Name Dispute Resolution, at http://www.icann.org/udrp/ approved-providers.htm (page updated Apr. 14, 2001) [hereinafter ICANN APPROVED Providers]. Since this article was written, eResolution has folded its operation and stopped accepting ICANN arbitration proceedings. It blames the pro-complainant bias of WIPO coupled with the complainant's privilege to choose the DRP. See id. (page updated Nov. 31, 2001). See also Press Release, eResolution (Nov. 31, 2001), http://www.eresolution.com/default.htm; Kieren McCarthy, eResolution quits domain arbitration, REGISTER, Dec. 4, 2001, at http:// theregister.co.uk/content/6/ 23175.html. 
3. the domain name has been registered and is being used in bad faith.

The Policy also provides a non-exhaustive list of circumstances that are "evidence" of bad faith:

1. circumstances indicating that the domain name holder registered or acquired the domain name primarily for the purpose of selling, renting, or otherwise transferring the domain name registration to the complainant who is the owner of the trademark or service mark or to a competitor of that complainant, for valuable consideration in excess of documented out-of-pocket costs directly related to the domain name; or

2. the domain name was registered in order to prevent the owner of the trademark or service mark from reflecting the mark in a corresponding domain name, provided that the domain name holder has engaged in a pattern of such conduct; or

3 . the domain name was registered primarily for the purpose of disrupting the business of a competitor; or

4. by using the domain name, the owner has intentionally attempted to attract, for commercial gain, Internet users to its web site or other on-line location, by creating a likelihood of confusion with the complainant's mark as to the source, sponsorship, affiliation, or endorsement of its web site or location or of a product or service on its web site or location. ${ }^{24}$

The domain name holder (the "respondent" under the ICANN policy) has three possible affirmative defenses (note, however, that their elements overlap considerably with the complainant's burden of proof):

1. before any notice of the dispute, the domain name holder used, or made demonstrable preparations to use, the domain name or a name corresponding to the domain name in connection with a bona fide offer of goods or services; or

2. the domain name holder has been commonly known by the domain name (even absent a trademark or service mark); or

3. the domain name holder is making a legitimate noncommercial or fair use of the domain name, without intent for commercial gain to misleadingly divert consumers or to tarnish the trademark or service mark at issue. ${ }^{25}$

These standards involve the resolution of fact-intensive issues like confusing similarity, bad faith, intent behind registration, fair use, and whether conduct would tarnish a trademark or service mark. As various arbitrators interpret the Policy, the question of whether a complainant has met her burden also involves the question of whether the complain-

24 UDRP, supra note $16, \S 4$.

25 Id. The ICANN Policy is similar to U.S. law, but it is not in fact the same as the law of any actual country. For example, compare the Policy to the Anti-Cybersquatting Consumer Protection Act (ACPA), 15 U.S.C. $\$ 1125$ (d) (2000). See Emerson H. Tiller, ICANN's Uniform Domain Name Dispute Resolution Policy: An Overview and Critique, 1 INTERNET L. \& Bus. 589, 591-93 (2000) (listing some of the differences between the UDRP and the ACPA). 
ant has established a nonregistered common law mark. Except in the most blatant cybersquatting cases, the resolution of such fact-based disputes should involve procedural devices such as discovery, ${ }^{26}$ live hearings, and cross examination. ${ }^{27}$ The main point of this policy, however, is that it is fast and cheap. The complaint is filed in writing. It must describe the manner in which the domain name is similar to the trademark, why the domain name holder has no rights in the mark, and why the domain names should be considered as registered and used in bad faith. The complaining trademark owner must also attach documentary or other evidence, including any trademark or service mark registration. ${ }^{28}$ The complainant pays the filing fee, which varies by DRP, the number of domain names involved, and whether either party opts for a three-member panel. Because this complaint will, in effect, form the basis for the decision, it will probably contain more factual detail than "notice pleading" would require. ${ }^{29}$

${ }^{26}$ As one trained in the U.S. procedural system, I use the term "discovery" to refer to the system for gathering relevant information and bringing it to the attention of the fact finder. Other systems use other methods that result in parties having access to information formerly in the hands of their opponents, whether it be investigation by the judge, document disclosure, pre-action protocols, or particularized fact pleading. My argument here is not that the system needs to precisely replicate American discovery methodology, but only that some mechanism for allowing exchange of information is essential if the process will result in findings regarding disputed facts.

27 The World Intellectual Property Organization (WIPO), which drafted the initial version of the UDRP, was asked to recommend whether the UDRP should be expanded into other areas. In its Final Report on the subject, WIPO comments that in more fact-intensive disputes the streamlined UDRP might not be adequate. WIPO, The Recognition of Rights and the Use of Names in THE INTERnet Domain Name SYSTEM (Sept. 3, 2001), I 318(iii), at http://wipo2.wipo.int/process2/report/html/ report.html [hereinafter WIPO, THE RECOGNITION OF RIGHTs] ("The UDRP was designed for . . . straight-forward disputes. . . . It was not designed to accommodate disputes involving interests on both sides, which requires a more extensive procedure, perhaps involving the hearing of evidence and oral arguments.").

${ }_{28}$ The DRP is allowed to impose page or word limits on the complaint, response, and opinion. For example, CPR and NAF each impose a ten page limit on complaint and response. CPR Instrtute for Dispute Resolution, CPR's Supplemental Rules AND FeE SCHEdule, paras. 4-5, at http://www.cpradr.org/ICANN_RulesAndFees.htm (last visited Nov. 7, 2001) (on file with the Journal of Small and Emerging Business Law); Nat'l Arbitration Forum, Uniform Domain Name Dispute Resolution POlicy “UDRP” SUPPlemental Rules (2001), at http://www.arbforum.com/ domains/UDRP/ rules.asp (Oct. 15, 2001). The parties can circumvent these limits, however, by designating filings as attachments.

29 The legal fees involved would likely be more than required for merely drafting a court complaint, but far less than would be required to litigate a preliminary injunction request. It is possible, therefore, that a trademark owner who expects the domain name holder to default would actually be better off filing a lawsuit in federal court, where the filing fees would be less than the cost of the ICANN filing. Both filing fees and the cost of preparing the initial document would be lower in federal court. The Eastern District of Virginia, the federal district in which Network Solutions, Inc. is located, has held that the act of registering the domain name is a 
The domain name holder/respondent must be notified within three calendar days and has twenty days from the commencement of the proceeding to submit a response. That response should specifically address the statements in the complaint as well as any applicable affirmative defenses. If the respondent wants a three-member panel rather than a single arbitrator, it must pay half the applicable fee ${ }^{30}$ If the respondent fails to respond, the case will be decided based on the complaint. ${ }^{31}$ The arbitrator has the power to determine the admissibility, relevance, materiality, and weight of the evidence, and may request further statements and documents from the parties. The Rules provide that there "shall be no inperson hearings (including hearings by teleconference, videoconference, and web conference)" unless the arbitrator "determines, in its sole discretion and as an exceptional matter, that such a hearing is necessary for deciding the complaint." ${ }^{2}$ The arbitrator is directed to forward a decision on the complaint to the DRP within fourteen days of his appointment. The decision should be in writing and provide the reasons on which it is based. If the arbitrator rules for the complainant, ICANN will require the cancellation of the domain name or its transfer to the com-

sufficient basis for establishing specific personal jurisdiction there in a suit under the Anticybersquatting Consumer Protection Act, 15 U.S.C. $\$ 1125(\mathrm{~d})$. Lucent Techs., Inc. v. Lucentsucks.com, 95 F. Supp. 2d 528 (E.D. Va. 2000). But see AOL, Inc. v. Huang, 106 F. Supp. 2d 848 (E.D. Va. 2000). Even if the defendant unexpectedly answers, the Eastern District is the home of the "rocket docket" which emphasizes limited discovery and early trial settings. The ACPA also has an in rem provision that has been upheld by some courts. See, e.g., BroadBridge Media, L.L.C. v. Hypercd.com, 106 F. Supp. 2d 505 (S.D.N.Y. 2000); Heathmount A.E. Corp. v. Technodome.com, 106 F. Supp. 2d 860 (E.D. Va. 2000).

${ }^{30}$ The fees vary by provider, and vary according to the number of domain names in dispute, but the total fee for multiple panelists would be between $\$ 2,500$ and $\$ 6,000$ for most cases. See, e.g., CPR Instrtute fOR DisPUTE Resolution, supra note 28, para. 13; eResolution, SCHEdule of FeEs, at http://www.eresolution.ca/services/ dnd/schedule.htm (last modified Oct. 15, 2001); NAT'L ARBITRATION Forum, supra note 28, § 16; WIPO, Schedule of Fees UNder the ICANN Policy (Aug. 15, 2000), at http://www.arbiter.wipo.int/domains/fees/index.html. When a three-member panel is used, the complainant and respondent each propose three potential panelists (the DRP chooses among them if available), and the DRP chooses the third after soliciting reactions to a list of five potential panelists. ICANN RuLes, supra note $16, \S \S 3(\mathrm{~b})$, $5(\mathrm{~b})(\mathrm{v}), 6(\mathrm{e})$. ICANN refers to even a single decisionmaker as a "panelist." I have used the word "arbitrator" instead so as not to imply that a "panel" composed of multiple persons exists.

31 Some decisions have indicated that failure to respond is proof of bad faith. See, e.g., AFC Enters. v. Max Mktg., Case No. D2000-0975 (WIPO Oct. 12, 2000) (Lisman, Arb.), at http://www.arbiter.wipo.int/domains/ decisions; Mars, Inc. v. Vanilla, Ltd., Case No. D2000-0586 (WIPO Sept. 1, 2000) (Partridge, Panelist), at http:// arbiter.wipo.int/domains/decisions; Ty, Inc. v. O.Z. Names, Case No. D2000-0370 (WIPO June 27, 2000) (Abel, Panelist), at http://www.arbiter.wipo.int/domains/ decisions; Suntex Int'l, Inc. v. 24game, Case No. D2000-0408 (WIPO June 26, 2000) (Methvin, Panelist), at http://www.arbiter.wipo.int.domains/decisions.

32 ICANN Rules, supra note $16, \S 13$. 
plainant. ${ }^{33}$ The only way for the domain name holder to prevent the cancellation or transfer is to file a lawsuit against the trademark owner and provide a file-stamped copy of the complaint to ICANN within ten business days. ${ }^{34}$ There is no internal appeal. The whole process should thus be resolved in less than two months.

The original purpose of the ICANN dispute resolution process was to create a remedy for a narrowly defined group of particularly egregious cases. During the initial drafting process, the procedure was said to be available "only in respect of deliberate, bad faith, abusive, domain name registrations or 'cybersquatting." 35 ICANN's staff repeated this promise after receiving public comments on the proposed policy. They assured concerned commentators that "the policy ... calls for administrative resolution for only a small, special class of disputes," namely those "involving 'abusive registrations' made with bad faith intent to profit commercially from others' trademarks." ${ }^{36}$ Nevertheless, the dispute resolution procedure has been used in all sorts of trademark/domain name disputes. Between December 1, 1999 and July 31, 2001, ICANN disposed of 3,316 domain name disputes by decision, involving 5,975 domain names. Of these dispositions, only about $19 \%$ were decided in favor of the domain name holder. ${ }^{37}$ The rest resulted in transferring the domain name to the trademark owner $(2,616)$, canceling the domain name (28), both canceling and transferring the challenged names (1), or in a split decision $(21) .{ }^{38}$

33 No provisions exist for money damages.

34 The lawsuit must be filed in a "mutual jurisdiction," which will generally be either the location of the domain name registrar's principal office or the domain name holder's residence as shown in the registrar's Whois database at the time the complaint is filed. UDRP, supra note $16, \S 4(\mathrm{k})$; ICANN RuLEs, supra note $16, \S \S 1$, 3(xiii).

35 WIPO, The Management of Internet Names and Addresses: InTEllectual. Property Issues $\$ 135$ (i) (Apr. 30, 1999), at http:// wipo2.wipo.int/process1/report/ finalreport.html [hereinafter WIPO, MANAGEMENT OF INTERNET NAMES]. See also NAT'L Telecomms. \& Info. Admin., Dep't of Commerce, Management of Internet Names AND ADDRESSES, June 10, 1998, 1998 WL 298883 (F.R.)

([W]hatever dispute resolution mechanism is put in place by the new corporation, that mechanism should be directed toward disputes about cybersquatting and cyberpiracy and not to settling the disputes between two parties with legitimate competing interests in a particular mark. Where legitimate competing rights are concerned, disputes are rightly settled in an appropriate court.)

36 ICANN, Second Staff Report on Implementation Documents for the Uniform Dispute Resolution Policy $\$$ 4.1(c) (Oct. 24, 1999), at hitp:// www.icann.org/udrp/udrp-second-staff-report-24oct99.htm.

37 ICANN, Statistical Summary of Proceedings Under Uniform Domain Name DisPute Resolution POlicy, at http://www.icann.org/udrp/ proceedings-stat.htm (page updated Nov. 6, 2001). Conversely, one could say that $79.76 \%$ of the proceedings were resolved wholly in favor of the complainant, with some additional victories included in the split decisions.

38 Id. 
The ICANN process is mandatory in the sense that once a complaint is filed it will be processed by the dispute resolution provider unless the complaint is settled or withdrawn. If the domain name holder does not respond to the complaint, she will almost certainly lose, and ICANN will order her domain name transferred or canceled.

The ICANN process is not mandatory in the sense that the rules do not preclude the filing of a lawsuit, either during the proceeding ${ }^{39}$ or after its conclusion. A trademark owner who believes that, given the particular circumstances, a federal lawsuit would be more advantageous is free to pursue that option instead of, or in addition to, the ICANN procedure. ${ }^{40}$

It should be clear from the above description that the UDRP's operation is essentially a private process. ICANN itself is a private, nonprofit corporation whose policies are shaped both by governments and by influential private entities. ICANN has needed and still needs "the concurrence of every powerful party with an interest in domain name policy." 41

39 The arbitrator has the discretion to stay the ICANN proceeding (or not) during the pendency of court litigation. UDRP, supra note $16, \S 18(\mathrm{a})$. It is unsettled at this time whether ICANN decisions will receive some degree of deference in any related litigation. See, e.g., Weber-Stephen Prods. v. Armitage Hardware \& Bldg. Supply Inc., 54 U.S.P.Q.2d 1766 (N.D. Ill. 2000); Weber-Stephen Prods. v. Armitage Hardware, Case No. D2000-0187 (WIPO May 11, 2000) (Powers, Panelist), at http:// www.arbiter.wipo.int/ domains/decisions. In U.S. courts, at least, a tradition of deference does not seem to be developing. For example, in Parisi v. Netlearning, Inc., 139 F. Supp. 2d 745, 752 (E.D. Va. 2001), the court refused to apply the deferential review standards of the Federal Arbitration Act to the UDRP decision. In another case, the district court ruled differently from the prior UDRP decision between the same parties without citing that decision or explaining why it disagreed with the arbitrator. Compare Referee Enters., Inc. v. Planet Ref, Inc., Case No. 00-C-1391 (E.D. Wis. Jan. 24, 2001), at http://www.Loundy.com/cases, with Referee Enters. v. Planet Ref, Inc., File No. FA0004000094707 (NAF June 26, 2000) (Kupferman, Arb.), at http://www.arbforum.com/domains/decisions.

${ }^{40}$ It appears that a domain name holder who loses an ICANN proceeding can successfully invoke the jurisdiction of a U.S. federal court to secure a judicial determination of its rights. See Sallen v. Corinthians Licenciamentos LTDA, No. 011197, 2001 U.S. App. LEXIS 25965 (1st Cir. Dec 5, 2001) (finding federal jurisdiction under ACPA). See also Plaintiff's Complaint, Barcelona.com v. Excelentisimo Ayuntamiento de Barcelona (E.D. Va. Filed Aug. 17, 2000) (complaint contesting UDRP decision regarding barcelona.com brought under $\$ 1114(2)$ of the ACPA), http://www.domainbattles.com/lawsuit3.htm. 15 U.S.C. $\$ 1114$ (2) (D) (v) creates a civil cause of action for domain name registrants whose registrations are cancelled or transferred.

41 Jonathan Zittrain, ICANN: Between the Public and the Private Comments Before Congress, 14 BERkeley TECH. L.J. 1071, 1083 (1999). WIPO, the original drafter of the UDRP and largest processor of domain name disputes, has also been accused of being captive to corporate interests.

What we're looking at here is a coup by WIPO over every other body set up to resolve Internet argy-bargy. And how do you run a coup? You get either military [or] the money-makers on your side. Seeing as there isn't any Internet military, it has gone for the fat and rich corporations. 
In addition to governments (especially the U.S. and the European Union), this "concurrence" includes Internet engineering groups and trademark interests. ${ }^{42}$ ICANN "faces swift dispatch if it strays too far from the desires of . . p powerful corporate interests." 43 ICANN developed its domain name dispute policy and the rules for implementing it with the input of these key groups. ${ }^{44}$ The following sections analyze how fairly this privatized dispute resolution system solves the problems of Internet uncertainty.

\section{SUCCESSES: WHAT ICANN DOES RIGHT}

At a level of platitudes, there is general consensus about the requirements for a fair and effective system of dispute resolution. ${ }^{45}$ For example, the Center for Law, Commerce \& Technology lists independence, low cost, transparency, adversarial procedure, representation, legality, and liberty as the essential elements of an ODR scheme. ${ }^{46}$ The Better Business Bureau system has a similar list: fairness, visibility, accessibility, timeliness, finality, and enforcement. ${ }^{47}$ The UDRP has elements that satisfy some of these requirements.

Kieren McCarthy, Who the hell does WIPO think it is?, RegisTer, Aug. 16, 2000, at http:// www.theregister.co.uk/content/5/12638.html.

42 Zittrain, supra note 41, at 1083.

43 Id. at 1091 .

44 The initial version of the policy was actually developed by WIPO. A number of governments have recently appealed to WIPO to consider amending the domain name system to handle issues such as famous names, geographic locations, and "untrademarked" trade names. See Michael Geist, WIPO Wipes Out Domain Name Rights, Globe \& MAIL, Aug. 24, 2000, at http://www.globetechnology.com/archive [hereinafter Geist, WIPO Wipes Out Rights]. While WIPO's interim report leaned in favor of expanding the UDRP to geographical, personal, and trade names, the final report concedes that the lack of international consensus on applicable law would make such an expansion inappropriate. WIPO, MANAGEMENT OF INTERNET NAMES, supra note 35, II 65-76. However, ignoring this correctly limited approach, ICANN at its recent meeting in Montevideo voted to give countries exclusive rights to country names in the new .info TLD. See ICANN, Preliminary Report, MEetinc of the ICANN BOARD IN MONTEVIDEO (Sept. 10, 2001), at http://www.icann.org/minutes/ prelim-report- 10sep01.htm.

${ }^{45}$ Most of the discussion of ODR has been in the context of business-toconsumer (B2C) commercial transactions. The implementation of the standards on the list would undoubtedly have to be modified for other kinds of Internet-related disputes.

46 Center for Law, Commerce \& Technology, University of Washington School of Law, Online Alternative Dispute Resolution: An Issues Primer 19 (2000), at http://www.law.washington.edu/lct/publications.html (prepared for the National Association of Attorneys General). See also Commission Recommendation on the Principles Applicable to the Bodies Responsible for Out-of-Court Settlement of Consumer Disputes, Commission Report 98/257, at 31 (Apr. 17, 1998), at http:// europea.eu.int/comm.consumers/policy/developments (listing independence, transparency, adversarial principle, effectiveness, legality, liberty, and representation).

47 Council of Better Business Bureaus, Inc. \& BBBOnLine, Protecting Consumers in Cross-Border Transactions: A Comprehensive Model for 
The UDRP allocates most of the administrative cost of a proceeding to the complaining trademark holder. ${ }^{48}$ This is most likely to be the party with greater resources. Although the cost will be at least $\$ 950$, the commercial value of a domain name can be so substantial that the administrative cost are likely proportional to the value in controversy from the perspective of a complaining trademark holder. The UDRP does not require the parties to hire attorneys to prepare the complaint and response, and doing so would add to the cost of pursuing or defending the proceeding. ${ }^{49}$ In all but default proceedings, however, the limited nature of the UDRP process is likely to require less attorney time than a conventional lawsuit. ${ }^{50}$ Even though the DRP's fees have already increased by at least $50 \%$ in the short time the policy has been in operation, it is still regarded as a bargain by trademark holders. ${ }^{51}$

The UDRP also succeeds in being a process that resolves disputes quickly. Most of the cases are disposed of within the allotted times, which are themselves very short. The ability to transmit information electronically undoubtedly adds to the speed of the process. While the process achieves speed by allowing very little input and by limiting the issues involved, it must be said that speed was the drafters' primary goal and it

Alternative Dispute Resolution (2000), at http://www.bbbonline.org/ about/ press/whitepaper.doc.

48 UDRP, supra note $16, \S 4(\mathrm{~g})$ (complainant pays filing fees, except that respondent pays half the fees if respondent requests three member panel). However, the cost of half-fees for a three-member panel may deter respondents from requesting this more reliable procedure. In addition, some of the DRPs-by supplemental ruleimpose additional fees that might have to be paid by respondent. For example, some DRPs charge extra if the party wants to receive communication by fax or courier rather than by email. See ERESOLUTION, supra note 30 ( $\$ 100$ for fax, $\$ 250$ for courier). NAF charges a filing fee for respondents to request an extension of time $(\$ 100)$ or when either party requests the opportunity to submit additional written statements or documents (\$250). NAt'L Arbitration Forum, supra note 28, $\$$ 6(a) (v), 7(b) (ii).

49 "Complainants are usually companies who are represented either by in-house or external trademark counsel. The respondents are frequently unrepresented, although one does come across cases where corporate respondents use trademark counsel." Webster, supra note 17, at 227. The theoretical benefit of not requiring attorneys may disadvantage respondents in practice, if their pro se defense is overpowered by a lawyer-drafted complaint.

50 Elizabeth G. Thornburg, Going Private: Technology, Due Process, and Intermet Dispute Resolution, 34 U.C. DAvIS L. REv. 151, 163 n.43 (2000) (comparing cost of UDRP filing with default judgment case in U.S. federal court).

51 Commentators have noted that the fees paid to UDRP arbitrators are modest in comparison with what they could otherwise make as practicing attorneys or in deciding more conventional arbitral matters. See, e.g., Helfer \& Dinwoodie, supra note 19, at 231. Since this article was written, NAF raised its fees in cases involving one to five disputed domain names. See Nat'l Arbitration Forum, UDRP Schedule of FEES, http://www.arbitration-forum.com/domains/UDRP/feesl asp (last visited Jan. 26, 2002) (new fees); http://www.arbitration-forum.com/domains/UDRP/fees.asp (old fees). 
was successfully accomplished. ${ }^{52}$ Note, however, that this speed is far more likely to benefit the complainant than the respondent.

The ICANN process is also transparent in some respects. First, both the substantive ${ }^{53}$ and the procedural provisions of the UDRP are posted on the ICANN web site and are easily accessible. ${ }^{54}$ Second, any arbitrator deciding an individual case must render the decision in writing, and the decision must explain the reasons for the result. ${ }^{55}$ Third, those decisions are usually made publicly available; they are posted on the DRP's websites and indexed by party and commencement date. ${ }^{56}$ Thus anyone who has

52 The speed can be used to add further disadvantage to respondents. Under the ICANN Rules, the proceeding is commenced when the DRP forwards the complaint to respondent. ICANN Rules, supra note $16, \S 4(\mathrm{c})$. This transmission is done by email and by hard copy, but the attachments (which are in hard copy) are generally sent by snail mail. Id. $\S 2(\mathrm{a})$. Respondent has only twenty days from "commencement," however, to submit a response. Id. $\$ 5$ (a). Given the global coverage of the UDRP, a respondent might not have received the attachments before the response deadline runs, and will certainly receive less than the apparent twenty days. If significant information is contained in the attachment but not in the actual complaint, this combination of rules exacerbates the parties' unequal benefit from the speed of process.

53 The written policy introduces elements of uncertainty, however, because paragraph 15 of the ICANN Policy (UDRP) directs the arbitrator to decide the complaint based not only on the UDRP itself, but also on "any rules and principles of law that it deems applicable." UDRP, supra note $16, \S 15(\mathrm{a})$.

54 The ICANN website also provides links to the Supplemental Rules of the approved DRPs. ICANN APPROVEd Providers, supra note 23.

55 UDRP, supra note $16, \S 15(\mathrm{~d})$. This provision is sometimes described as a requirement of arbitral due process. See Am. Arbitration Ass'n, Consumer Due Process Protocol: Statement of Principles of the National Consumer Disputes Advisory COMMITTEE, http://www.adr.org/education/education/consumer_protocol. HTML (LAST VISITED NOV. 7, 2001) (PROVIDING THAT “[A]T THE TIMELY REQUEST OF EITHER PARTY, THE ARBITRATOR SHOULD PROVIDE A BRIEF WRITTEN EXPLANATION OF THE BASIS FOR THE AWARD"); see also Richard C. Reuben, Constitutional Gravity: A Unitary Theory of Alternative Dispute Resolution and Public Civil Justice, 47 U.C.L.A. L. REv. 949, 1085 (2000) (explaining that written opinions make the process more democratic, enhance the integrity and legitimacy of the process, provide rationality and transparency in an otherwise arbitrary process, perform a persuasive and educational function, and can coalesce into a collective arbitral wisdom).

${ }^{56}$ Because the volume of UDRP decisions has reached into the thousands, the decisions are not practically useful or meaningfully transparent in the absence of an indexing system or thoroughly searchable database. Such systems are in development. The Berkman Center for Internet and Society at Harvard has created a search engine that allows some searching of the database of decisions. See ICANN, SEARCh Decisions in Proceedings Under the Uniform Domain Name Dispute Resolution Policy, at http://www.icann.org/udrp/udrpdec.htm (last visited Nov. 7, 2001). Professor Michael Geist of the University of Ottawa has created a database of ICANN decisions searchable for information about panelists' participation. See UDRPINFo.com, at http://www.udrpinfo.com (last visited Nov. 7, 2001). As the volume of UDRP decisions grows ever larger, a better system of indexing will be necessary to perform searches such as finding cases deciding particular issues. The UDRP Publishing Protocol Project, in response to this dilemma, is attempting to develop more uniform reporting standards. See UDRP Publishing Protocol Project, at http:// 
the time and energy can read the opinions and personally assess whether the arbitrator has correctly applied the ICANN Policy to the facts as described. ${ }^{57}$ It also allows the general public to watch for any troubling patterns of behavior by complainants, respondents, or the DRPs. ${ }^{58}$ Absent the public availability of the decisions, the problems discussed herein would still exist but would be unknown.

One of the thorniest problems of ODR is making its decisions enforceable. ${ }^{59} \mathrm{~A}$ compliant party called upon to perform presents no procedural difficulty. However, either a party who has second thoughts about a mediation agreement, or a party who loses a binding arbitration scheme, may not comply. In this case, the party entitled to performance would have to bring a court action to enforce the agreement, ${ }^{60}$ thus reviving many of the legal and practical obstacles discussed in Section I.

udrp.law.cornell.edu/udrp (last modified Nov. 15, 2001). Note, however, that it is universities and foundations rather than ICANN itself that are providing this more effective transparency.

57 Because the decisions often seem to be selectively quoting allegations rather than finding facts, ICANN should also post the parties' pleadings and supporting documents. If these documents revealed trade secrets or proprietary information, they could be redacted. This practice would shed more light on the ways in which arbitrators are actually applying the UDRP.

${ }^{58}$ For example, critics have noted the following: WIPO arbitrators' tendency to favor trademark owners (Laurence R. Helfer, International Dispute Settlement at the Trademark-Domain Name Interface, 29 PEPP. L. REV. (forthcoming 2001) (manuscript on file with the Journal of Small and Emerging Business Law)); a pattern of decisions that (at least by U.S. standards) undervalue free speech interests (Dori Kornfeld, Comment, Evaluating the Uniform Domain Name Dispute Resolution Policy, at http:// cyber.law.harvard.edu/icann/pressingissues $2000 /$ briefingbook/udrp-review.html (last updated Oct. 31, 2000)); decisions that conflict in their interpretations of the ICANN Policy (UDRP) or Rules (Robert A. Badgley, Improving ICANN in Ten Easy Steps: Ten Suggestions for ICANN to Improve its Anti-Cybersquatting Arbitration System, 2000 J.L. TECH. \& Pol'y 109, 113-14 (2000)); and decisions that conflict with the policy as written (Ian L. Stewart, The Best Laid Plans: How Unrestrained Arbitration Decisions Have Corrupted the Uniform Domain Name Dispute Resolution Policy, 53 Fed. Coмm. L.J. 509, 510 (2001)).

59 Task Force on E-commerce \& Alternative Dispute Resolution, Am. Bar Ass'n, Draft Preliminary Report \& Concept Paper 4 (May 2001), http:// www.law.washington.edu/ABA-eADR/drafts/2001.05.2/draft.html ("One of the largest concerns with respect to ODR is the existence of means for enforcing outcomes. In many cases, the link between ODR and effective enforcement mechanisms remains unclear. . . . Without effective enforcement, the vitality of ODR may be severely hindered."); Brandon Mitchener, Cybercourts Emerge as Way to Resolve Internet Disputes, WALL ST. J., Mar. 21, 2000, http://interactive.wsj.com/articles/SB9 ("Arbitration experts say the ability to enforce decisions will be the acid test for any online dispute-settlement systems.").

60 Under certain circumstances, international arbitral awards may be enforceable under the New York Convention on Recognition and Enforcement of Arbitral Awards. In the United States, federal courts are given a broad grant of jurisdiction to enforce these awards. 9 U.S.C. $\$ 201$ (2000). There are certain obstacles, however, to using the New York Convention to enforce online arbitral awards. For a discussion of 
ICANN has largely succeeded in solving the enforcement dilemma, although it is not a solution that could easily be replicated in a different context. Because ICANN has a contract with Network Solutions, Inc., which controls the computer that physically assigns each domain name, it can itself enforce the UDRP decision. A winning complainant will either be awarded the domain name at issue or the name will be cancelled. Either way, the respondent will no longer be able to use it. This will not be true if the respondent files a lawsuit within ten days of ICANN's receipt of notice of the arbitrator's decision. ${ }^{61}$ However, so far only about twenty-five cases have been filed "appealing" the UDRP decision, ${ }^{62}$ leaving others effectively final. The process is therefore largely successful in providing the participants with a final and enforceable result.

In summary, ICANN adopted a process that succeeds in some ways, especially from the standpoint of trademark holders. It is well tailored to meet the primary goal of providing a fast, low-cost remedy. The UDRP also achieves some level of transparency of rules and results. Unfortunately, there are other ways in which the ICANN process falls far short of due process ideals. The next section of the article explores these concerns.

\section{FAILURES: PROBLEMS OF LEGITIMACY AND FAIRNESS}

ICANN's successes have been accompanied by the kinds of problems that one might expect in a privatized process. Anyone considering using the UDRP as a model for resolving other kinds of Internet disputes must pay heed to these failures as well. The lessons include the questionable legitimacy of privately-adopted substantive standards, the danger of unprincipled "choice of law" decisions to fill in the gaps in that private law, unreconciled splits among arbitrators as to the meaning of the standards, and a tendency to expand beyond the narrow "jurisdictional" limits of the policy. The UDRP also demonstrates that procedural choices can exacerbate substantive ones when private processes are imposed without true consent, when procedural rules unevenly impact the parties, and when procedures designed primarily to be fast are allowed to frustrate other due process values.

these, see M. Scott Donahey, Current Developments in Online Dispute Resolution, 16 J. INT'L ARB. 115 (1999).

${ }^{61}$ UDRP, supra note $16, \S 4(\mathrm{k})$.

${ }^{62}$ There is no systematic record tracking such cases. ICANN would receive the notices, and therefore would be in the best position to provide information about the filings, but this information is not available on its web site. The Uniform Domain Name Dispute Resolution Policy Legal Information Site has attempted to compile as complete a list as possible. See UDRPLAw.NET, CoMPLETE LiST OF UDRP CHALlENGES IN CourT, at http://www.udrplaw.net/UDRPappeals.htm (last visited Nov. 7, 2001). 


\section{A. Lessons About Creating Law}

It is understandably frustrating to work in an environment in which multiple, possibly inconsistent laws may apply. It is also understandable that an industry faced with this dilemma would simultaneously try to minimize the uncertainty and nudge the law in its favor. Nevertheless, the fact that the desire of trademark holders is understandable provides "no policy reason why we should design the architecture of the system to assist them." 63 ICANN's creation of its own international trademark $\operatorname{law}^{64}$ is inherently controversial. What right does a California nonprofit corporation have to create and impose law that differs from the law of nationstates?65

National interests have a role to play in the development of international solutions. Passing over them too quickly disserves a truly international solution by ignoring helpful laboratories of laws, failing to take advantage of developed democratic political structures that nation states (on the whole) provide, and ignoring the legitimate claims of nation states to (partial) legislative competence. ${ }^{66}$

ICANN is a particularly problematic example because many believe that its formation and subsequent policies suffered from the over-influence of trademark holders, thus skewing the substantive and procedural rules in their favor. ${ }^{67}$ Similarly, the recent appointment of a task force to

63 Jessica Litman, The DNS Wars: Trademarks and the Internet Domain Name System, 4 J. Smail \& Emerging Bus. L. 149, 157 (2000).

64 David G. Post, Why Juries Should Play a Role in the Institutions that Govern Cyberspace-Part I, Findlaw's CommentaRY, Oct. 27, 2000, at http:// writ.news.findlaw.com/commentary/200/027_post.html (explaining that the UDRP is, in effect, law).

65 "As the European Commission has soberly noted: 'ICANN . . . [is] taking decisions of a kind that governments would, in other contexts, expect to take themselves in the frameworks of international organisations." Andrew Orlowski, ICANN Special: The Triangulations of Esther Dyson, REGISTER, at http:// www.theregister.co.uk/content/6/ 13061.html (posted Sept. 6, 2000) (on file with the Journal of Small \& Emerging Business Law). Cf. Jay P. Kesan \& Rajiv C. Shah, Fool Us Once Shame on You - Fool Us Twice Shame on Us: What We Can Learn from the Privatizations of the Internet Backbone Network and the Domain Name System, 79 WASH. U. L.Q. 89 (2001) (discussing how privatization led to self-dealing and poor design choices).

${ }^{66}$ Graeme B. Dinwoodie, (National) Trademark Laws and the (Non-National) Domain Name System, 21 U. PA. J. INT'L ECON. L. 495, 510 (2000).

67 See Milton Mueller, ICANN and Internet Governance, I INFO. 497 (1999), http:// www.icannwatch.org/archives/muell.pdf (on file with the Journal of Small \& Emerging Business Law); Froomkin on Governance, supra note 8, at 628

([T]here can be little debate that the public participation in the process has been dominated by intellectual property rights holders and their lawyers and trade associations. Similarly, the [WIPO] Secretariat staff appear to be very sincerely committed to WIPO's mission of the promotion of intellectual property rights so much so that to even think about 'capture' almost seems beside the point.);

Helfer, supra note 58 (noting that the UDRP's formation was "unduly rushed and heavily dominated by intellectual property interests"); Helfer \& Dinwoodie, supra 
study the UDRP has been criticized as similarly stacked in favor of intellectual property interests and existing dispute resolution providers. ${ }^{68} \mathrm{~A}$ recent internal study of ICANN governance has recommended decreasing the number of at-large board members (who represent the online public), which has prompted further questions about ICANN's legitimacy. ${ }^{69}$

If the various national laws were already fairly uniform, creating private law that assimilates them would be relatively nonproblematic. That is undoubtedly the reason that the ICANN Policy as written is mostly confined to cases of blatant cybersquatting. ${ }^{70}$ Considerable multinational differences, however, exist in the law governing trademarks and their attendant rights, as well as differences in the treatment of speech. ${ }^{71} \mathrm{Just}$ as these differences have undermined ICANN's claim to legitimacy in the domain name area, similar differences in national laws on consumer protection, antitrust, defamation, freedom of expression, advertising, trade disparagement, products liability, privacy, and other areas would be cause for concern if a non-national body attempted to create Internet law in those areas. Some of these topics would be especially questionable as they are generally considered to be "mandatory law"-those areas in which the underlying social policy is so strong that parties may not contract around it through choice of law clauses or the like. ${ }^{72}$

note 19 , at 178 (discussing critiques of ICANN's authority and the process resulting in the UDRP).

68 Names Council Selects UDRP Task Force Members, ICANN WATCH (2001), at http:/ /www.icannwatch.org/arataicle/php?sid=317.

69 At-Large Membership Study Committee, ICANN, Draft Report on ICANN AT LARGE MEMBERSHip (2001), at http://www.atlargestudy.org/ draft_final.shtml (recommending decreasing number of at-large directors from nine to five). See David McGuire, ICANN Board Member Blasts Governance Study, NewsByres, Aug. 29, 2001, at http:// www.washtech.com/news/netarch/12205-1.html (reporting reactions to report). In contrast, the NGO and Academic ICANN Study (NAIS) final report calls for an open, at-large membership with strong participation in policy matters and representation on the ICANN board equal to the total number of directors selected by supporting organizations. NGO \& ACADEMIC ICANN STUDY, ICANN, LEGITIMACY, and the Public Voice: Making Global Participation and Representation Work (2001), at http:// www.naisproject.org/report/final. See also Letter from Barbara Simons et. al. to ICANN (Mar. 8, 2001), at http://www.icannwatch.org/essays/ atlarge.htm (expressing concern about possible ICANN plan to eliminate at-large membership). For an informative discussion of the issues presented by the Department of Commerce delegation of power to ICANN, see generally Froomkin Wrong Turn, supra note 18, at 50-90; see also Jonathon Weinberg, ICANN and the Problem of Legitimacy, 50 DukE L.J. 187 (2000).

70 According to the Final Report of the second WIPO Internet Domain Name Process, the UDRP "does not seek to regulate the whole universe of interface between trademarks and domain name, but only to implement the lowest common denominator of internationally agreed and accepted principles concerning the abuse of trademarks." WIPO, THE RECOGNITION OF Rights, supra note 27, I 66 .

71 Dinwoodie, supra note 66 , at $500-01,508,551$.

72 Thornburg, supra note 50, at 213; Richard Shell, Contracts in the Modern Supreme Court, 81 CAL. L. REV. 431, 444 (1993) (discussing mandatory law as "market 
Even if one overlooks the democratic deficit and accepts ICANN's authority to make law, the policy also allows the arbitrators to apply "any rules and principles of law ... deem[ed] applicable." ${ }^{73}$ While this may seem like an innocent gap-filler, it has resulted in eclectic and unprincipled "choice of law" decisions as different arbitrators choose to apply various national laws ${ }^{74}$ or "principles of equity." 75 This re-introduces the uncertainty about applicable law that the UDRP was created to prevent. It also exacerbates the differences among the decisions made by the unappealable arbitrators, who not only interpret the Policy but also choose when and how to supplement it with national law with virtually no guidance from the ICANN Rules. ${ }^{76}$ This apparent need to consult national law, and, hence, the need for choice of law rules, may be a byproduct of trying to create enforceable private law in areas where national laws differ significantly. Any expansion of a UDRP-like process into areas with even greater international variation would cause even greater problems of this kind. ${ }^{77}$

inalienable"); see Stephen J. Ware, Default Rules from Mandatory Rules: Privatizing Law Through Arbitration, 83 MINN. L. Rev. 703 (1999).

73 UDRP, supra note $16, \S 15(\mathrm{a})$.

74 According to King, as early as May 2000, UDRP panels had used precedent and law outside the ICANN Policy and Rules at least 43 times. Stacey H. King, The "Law That It Deems Applicable": ICANN, Dispute Resolution, and the Problem of Cybersquatting, 22 Hastings Comm. \& ENT. L.J. 453, 484 n.139 (2000). One panelist applied U.S. trademark law to a dispute brought by a New Zealand company with offices in London, involving registration in Australia by an Australian citizen, on the basis that the panelist was "reasonably familiar with U.S. trademark law." Kornfeld, supra note 58, at 8, citing Tourism and Corporate Automation Ltd. v. TSI Ltd., Case No. AF-0096 (eRes Mar. 16, 2000) (Hardy, Panelist), at http://www.eresolution.ca/ services/dnd/decisions (commenting that "it is not feasible for any given arbitrator or panel to be familiar with all bodies of trademark and unfair trade law in all countries reached by the Internet").

75 Thomas \& Betts Int'l v. Power Cabling, Case No. AF-0274 (eRes Oct. 23, 2000) (Greenwood, Panelist), at http://www.eresolution.ca/services/ dnd/decisions.

${ }^{76}$ Supplementing the UDRP with national law can even taint the development of the "law" of ICANN as cases cite each other. For example, Case 1 might resolve an issue by applying one country's trademark law. Then, Case 2 cites Case 1 as an interpretation of the UDRP, regardless of whether the same national law would apply to the parties before it. See, e.g., Telestra Corp. v. Nuclear Marshmallows, Case No. D2000-0003 (WIPO Feb. 18, 2000) (Christie, Panelist), at http://arbiter.wipo.int/ domains/ decisions (citing as precedent an earlier case applying U.S. law in a case where both parties are Australian).

77 WIPO chose not to recommend expanding the UDRP to personal names, geographical names, and unregistered trade names partly because doing so would require extensive choice of law decisions. See WIPO, ThE RECoGnition of Rights, supra note 27, II 243, 318. Ironically, the report defends rather than disavowing existing WIPO decisions under the UDRP that apply national law to find protection for unregistered famous names. Id. II 182-84. Even cases cited in Annex $V$ to the Report demonstrate that UDRP arbitrators have sometimes simply applied previous ICANN decisions, regardless of the nationality of the parties. See, e.g., Rosa Montero Gallo v. Galileo Asesores S.I., Case No. D2000-1649 (WIPO Jan. 27, 2001) (Millé, Panelista) (Sp.) at http://www.arbiter.wipo.int/domains/decisions (citing earlier 
This problem could be minimized by allowing privatized, international rulemaking only in areas in which the international community has reached sufficient unanimity that resort to national law is not required. Otherwise, whether in the guise of creating substantive law or choice of law rules, the privatized body and its adjudicators would be making the kind of decisions better suited to democratic governments. Individual UDRP arbitrators should not be creating law by choosing or amalgamating possible national approaches.

Even when the Policy itself seems to cover the issue involved in a proceeding, different arbitrators interpret it differently. From a procedural perspective, for example, there are conflicting decisions about the effect of the respondent's default and about whether an arbitrator may allow a supplemental pleading that the arbitrator has not specifically requested. ${ }^{78}$ Substantively, there are also numerous split opinions concerning what constitutes a violation of the ICANN Policy. ${ }^{79}$ Because

ICANN decisions based on U.S. and U.K. law (if any), in a case involving parties who were both from Spain); Cho Yong Pil v. ImageLand, Inc., Case No. D2000-0229 (WIPO May 10, 2000) (Kim, Panelist), at http://arbiter.wipo.int/domains/ decisions.html (applying an earlier ICANN decision that involved company names and probably applied the law of India to a dispute about the name of a Korean pop star). A decision to leave "famous name" cases outside the UDRP would be more consistent with its drafting history and with WIPO, THE RECOGNITION OF RIGHTS, supra note 27 , and would avoid the need to deal with conflicting national laws.

${ }^{78}$ Badgley, supra note 58, at 113-14.

79 Winterson v. Hogarth, Case No. D2000-0235 (WIPO Mar. 22, 2000) (Perkins, Panelist), at http://www.arbiter.wipo/int/domains/decisions (protecting "famous" name); Sumner v. Urvan, Case No. D2000-0596 (WIPO July 24, 2000) (Christie, Panelist), at http://arbiter.wipo/int/domains/ decisions (not protecting famous name, citing drafting history of UDRP); Telestra, Case No. D2000-0003, para. 5.2 (finding that the passive holding of domain name satisfies "use" requirement); Sporoptic Pouilloux S.A. v. Wilson, Case No. D2000-0265 (WIPO June 16, 2000) (Introvigne, Panelist), at http://www.arbiter.wipo.int/domains.decisions (holding that registration alone, without "use," does not violate UDRP); Fire-Trol Holdings, L.L.C. v. Fire Foam Prods. Dev., Forum File No. NAF-FA93709 (NAF Mar. 20, 2000) (Perluss, Arb.), at http://www.arbforum.com/domains/decisions (finding famousness of mark relevant); Educ. Testing Serv. v. TOEFL, Case No. D2000-0044 (WIPO Mar. 16, 2000) (Abbott, Panelist), at http://arbiter.wipo.int/domains/ decisions (finding famousness irrelevant); Allocation Network GmbH v. Gregory, Case No. D2000-0016 (WIPO Mar. 24, 2000) (Wefers Bettink, Panelist), at http:// arbiter.wipo.int/domains/ decisions (holding that marketing of generic domain names is a legitimate use); J. Crew Int'l Inc. v. crew.com, Case No. D2000-0054 (WIPO Apr. 20, 2000) (Page, Panelist), at http://arbiter.wipo.int/domains/decisions (holding that one who speculates in domain names has no legitimate interest in those names); Adobe Sys. Inc. v. Domain OZ, Case No. D2000-0057 (WIPO Mar. 22, 2000) (Abbott, Panelist), at http://arbiter.wipo.int/ domains/decisions (finding that registration of four names constitutes a "pattern of conduct"); Kittinger Co. v. Kittinger Collector, Case Nos. AF-0107a and AF-107b (eRes May 8, 2000) (Thompson, Panelist), at http://www.eresolution.ca/services/dnd/decisions (finding that registration of four names is not a "pattern of conduct"); EAuto, L.L.C. v. EAuto Parts, Case No. D2000-0096 (WIPO Apr. 9, 2000) (Bernstein, Panelist), at http:// arbiter.wipo.int/domains/decisions (concluding that actual confusion is not required 
neither the Policy nor the Rules provide an internal appeal process, ${ }^{80}$ no mechanism exists for reconciling these inconsistent interpretations or deciding which should be followed and which ignored. Combined, the varying interpretations of the UDRP and the arbitrators' ability to incorporate unspecified legal principles undermine ICANN's goal of uniformity. Decisions under the UDRP can be as inconsistent and unpredictable as the decisions of various national courts. The privatization of disputes has not managed to eliminate the uncertainty that concerns global businesses.

Some of the inconsistent ICANN decisions reflect another characteristic of the UDRP - the ability of a theoretically limited process to expand beyond its intended limits. For example, in the process leading up to the adoption of the UDRP, it was consciously and deliberately decided not to include personal names or geographic terms, as international consensus was lacking concerning the extent to which such "marks" should be protected. $^{81}$ Nevertheless, the ICANN dispute resolution providers have accepted cases based on personal names and city names, and their arbitrators have ruled in favor of the complainants. ${ }^{82}$ ICANN panels have also exceeded policy limits by narrowly defining legitimate use (as when the panels find that noncompetitor sites that complain about the trademark holder are not legitimate) and by expanding the definition of bad faith (e.g., to include failure to respond to the complaint, or criticizing the complainant). ${ }^{83}$ After one panel has rendered an expansive decision, it can spread to other cases as the "law" of ICANN develops. ${ }^{84}$ Further, all

to show "likelihood of confusion"); CRS Tech. v. Condenet, Inc., File No.FA93547 (NAF Mar. 20, 2000) (Ayers, Arb.), at http://www.arbforum.com/domains/decisions (holding that evidence of confusion is required).

80 While there is theoretically a de novo "appeal" to national court systems, such an appeal is not of much practical use. See discussion infra note 137. In addition, those de novo appeals would apply the law of some nation state rather than the UDRP and ICANN Rules, and would be of little use in reconciling splits in interpretation of the ICANN documents.

81 WIPO, MANAGEMENT OF INTERNET NAMEs, supra note 35, paras. 165-68 (stating that process was purposely limited to trademarks and service marks. "Thus, registrations that violate trade names, geographical indications or personality rights would not be considered to fall within the definition of abusive registration for the purposes of the administrative procedure.").

82 See, e.g., Winterson, Case No. D2000-0235 (protecting "famous" name); Roberts v. Boyd, Case No. D2000-210 (WIPO May 29, 2000) (Page, Panelist), at http:// arbiter.wipo.int/domains/decisions (citing Winterson and protecting famous name "Julia Roberts"); Excelentisimo Ayuntamiento de Barcelona v. Barcelona.com, Case No. D2000-0505 (WIPO Aug. 4, 2000) (Porzio, Panelist), at http://arbiter.wipo.int/ domains/decisions (transferring barcelona.com from travel portal that had been using the domain name to City of Barcelona).

${ }_{83}$ Stewart, supra note 58, at 524-30.

${ }^{84}$ For example, the Julia Roberts proceeding cited an earlier WIPO proceeding that found protection of individual "famous" names involving British writer Jeanette Winterson. See supra note 82. A later case involving Boston radio personality Nik Carter cites both Winterson and Roberts. Carter v. Afternoon Fiasco, Case No. D2000- 
of this illicit expansion has been in one direction; it has favored trademark owners over domain name holders.

It is not surprising that the ICANN process suffers from the flaws of lack of legitimacy, uncontrolled choice of law decisions, inconsistent interpretation, and unwarranted expansion. It is, in a sense, "out of control." The institution's birth was intended to give weight to the concerns of intellectual property interests as Internet "stakeholders," and it did so. Even the most carefully drafted policy, especially a policy that will be applied to multinational actors and transactions, will have the potential to expand into areas in which national laws and policies differ. Further, because policies such as these are apt to be vague even (maybe especially) about important issues, interpretation will be needed as the policy is applied to various fact patterns. While some of these inequities could be lessened by better balancing ICANN's power structure and by tweaking the UDRP, they cannot be eliminated.

It is likely that the same kinds of problems will plague any ODR system, especially one designed by unevenly matched parties. This is not a problem unique to ICANN, but a problem inherent in attempts to privatize and make uniform law that is public and varied. While the mechanisms to check and confine privatized decisions could be stronger than those in the UDRP, the processes involve too many legal systems, too many conflicting policies, and too many people to be meaningfully confined to legitimate "law" except in an extremely restricted, routine, and harmonized area. Additionally, when the "legislative" choices are subject to the control of powerful interested parties, and those parties see the issues involved through the lens of their own concerns, the resulting substantive and procedural rules are apt to be slanted in their favor.

\section{B. Lessons About Creating Procedures}

ICANN sought two primary qualities in the UDRP: cheap and fast. It is indeed cheap and fast, but at the cost of other process values. As Professor Dan Burk pointed out to the House Courts and Intellectual Property Subcommittee, "While efficiency and speed are important aspects of a dispute resolution process, fairness is also important." 85 All parties can benefit when a dispute is processed without undue delay. The preparation and presentation of an international dispute, however, can take time, and there are limits to anyone's ability to accelerate a process without sacrificing adequate notice, accuracy, and the ability of parties meaningfully to participate. ${ }^{86}$ The UDRP's choices in the speed-fairness balance are another reason for caution in choosing it as a model for ODR.

0658 (WIPO Oct. 17, 2000) (Partridge, Panelist), at http://arbiter.wipo.int/ domains/decisions.

85 McGuire, supra note 17; cf. FED. R. Crv. P. 1 (overriding goals of federal rules).

86 Michael E. Schneider \& Christopher Kuner, Dispute Resolution in International Electronic Commerce, J. INT'L ARB., Sept. 1997, at 5, 10-11. 


\section{Forum Shopping}

One flawed ICANN Rule applies at the outset of the UDRP procedure: there are four approved dispute resolution providers, and the complainant is absolutely allowed to choose any one as the forum. If the track records of the entities were comparable, this might be a harmless error. As time passes, however, it is becoming increasingly obvious that this procedure is allowing outcome-based forum shopping. From a statistical standpoint, significant differences have emerged in the DRPs' tendency to rule for complainants. For example, WIPO panels have ruled for the complainant over $80 \%$ of the time, while eResolution and its arbitrators have found for the complainant less than $60 \%$ of the time. ${ }^{87}$ This difference, coupled with the complainant's right to choose, has led to an increasing tendency by complainants to choose WIPO. While WIPO received $29 \%$ of the complaints filed in January 2000, when the record of provider outcomes remained unpublished, by July 2000 it received $61 \%$ of the complaints filed. ${ }^{88}$ It has also been alleged that some DRPs subtly advertise themselves as pro-complainant. ${ }^{89}$ The privilege to forum-shop has added to doubts about the legitimacy of the process. ${ }^{90}$

\section{Mandatory Participation}

The ICANN procedure also violates the important principle of "liberty": domain name holders have no choice but to participate, or suffer the consequences, once the UDRP is invoked by the putative trademark holder. While the result is not technically binding, there is no way for the respondent to "opt out" of the process. Once the proceeding is filed, it will proceed to a conclusion. If the complainant prevails, ICANN will transfer or cancel the domain name unless the respondent assumes the burden of filing a lawsuit. Perhaps if domain name holders also had to consent to use of the private system after a dispute had arisen, the process would prove itself less one-sided. As the European Commission com-

87 Geist, WIPO Wipes Out Rights, supra note 44; ETHAN KATSH \& JANET RIfkIN, Online Dispute Resolution: Resolving Conflicts in Cyberspace 111 (2001).

88 Geist, WIPO Wipes Out Rights, supra note 44; KATSH \& RIFKIN, supra note 87, at 111 (tracking filing rates through Jan. 2001); Milton Mueller, Rough Justice: An Analysis of ICANN's Uniform Dispute Resolution Policy, at http://dcc.syr.edu/ roughjustice.htm (last visited Nov. 11, 2001) (finding forum shopping and bias in the UDRP) (on file with the Journal of Small and Emerging Business Law).

${ }^{89}$ King, supra note 74, at 500; Michael Geist, Fair.com?: An Examination of the Allegations of Systemic Unfaimess in the ICANN UDRP, UDRPINFO.COM, Aug. 2001, at 4, at http://aixl.uottawa.ca/ geist/geistudrp.pdf [hereinafter Geist, Fair.com?] (quoting NAF press releases with a "distinctly pro-complainant tone"). Cf. Trial Lawyers for Public Justice, Comments to Fed. Trade Comm'n, Comments on Mandatory Binding PreDispute Arbitration in the United States Today, Mar. 22, 2000, at 8, http://ftc.gov/bcp/ altdisresolution/comments/landjr.pdf (commenting on advertising by dispute resolution providers).

90 KATSH \& Rifkin, supra note 87, at 110-11. 
mented, "An effective, fair and rigorous $A D R$ scheme . . will be used without the need for compulsion." 1

It is technically true that the domain name holder has "consented" to the UDRP in its "contract" with the registrar who assigned the domain name, but this is a true contract of adhesion. ${ }^{92}$ There is no way to acquire a domain name ending in .com, .net, or .org without dealing with a registrar accredited by ICANN, and the UDRP is a mandatory part of the deal. The adhesive nature of the process would be equally objectionable if imported into the business-to-consumer (B2C) context, or even businessto-business (B2B) contracts involving significant power disparities, although in those cases it may be the claimants rather than the respondents who are the unwilling participants in the privatized process. A mandatory process would be even more unacceptable in cases involving no contractual consent whatsoever. The justification for an arbitral model, which eliminates procedural and substantive rights that would otherwise be present, is that the parties have consented to those reduced rights. ${ }^{93}$ No such consent is present in the UDRP.

\section{Slanted Procedural Rules}

The ICANN Rules, like most any system of procedural rules, also demonstrate another procedural truth: procedures can have uneven impacts, often predictably uneven impacts. A procedural system can be structured in a way that gives one side significant advantages. In this case, although most rules apply to both complainants and respondents, they will sometimes disadvantage respondents alone in operation. For example, the deadline to appeal an adverse panel decision is ten days for both parties. While this sounds parallel, consider the different situations in which the parties will find themselves. A losing complainant did not have control over the domain name before the ICANN process, still lacks control over the domain name after the ICANN process, and can in fact file a lawsuit at any time because the status quo has not changed. A losing respondent, on the other hand, will go from controlling the domain

91 Fed. Trade Comm'n, Dep't of Commerce, Comments by the European Commission on Alternative Dispute Resolution For Consumer Transactions in THE Borderless ONLINE MarketPlace (2000), at http://www.ftc.gov/bcp/ altdisresolution/comments.

${ }^{92}$ Cf. Menkel-Meadow, supra note 15 , at 52 (" $[\mathrm{T}]$ he contractual basis of arbitration is lost when consent is not real or where there are great power disparities between the parties."); Richard E. Speidel, Contract Theory and Securities Arbitration: Whither Consent?, 62 BROOK. L. REv. 1335, 1337 (1996) (“[T] he darker side [of consent] involves the scope of freedom from contract which arises in the so-called contract of 'adhesion.' How far may one party with superior bargaining power go to require arbitration, define the terms of the contract to arbitrate and control the procedures and processes of arbitration?").

${ }^{93}$ Helfer \& Dinwoodie, supra note 19, at 192. 
name to losing it unless a file-stamped copy is supplied to ICANN within ten days from when ICANN learned of the panel's decision.94

The supplemental rules of some DRPs also contain provisions that can disadvantage respondents. For example, while a complainant can choose the time to initiate the proceeding, waiting until it has compiled all necessary documentation and artfully drafted its pleading, the respondent has only twenty days from when the DRP sends the complaint to the complainant in which to respond. Under the NAF Supplemental Rules, the respondent may only request an extension of time if it confers with the complainant and files a request in writing along with a $\$ 100$ request fee, all within the original twenty day deadline. ${ }^{95}$ Thus, respondents, unlike complainants, must pay for the extra time required to prepare their only meaningful submission to the decisionmaker. ${ }^{96}$

\section{No Mechanism for Information Sharing}

The UDRP is also a flawed model for cases in which one party needs information from the other. In conventional litigation, discovery exists as a tool to provide all parties with access to relevant information. Once the parties are aware of that information, they can present a fuller account to the trier of fact. This, in turn, leads to more fair and accurate trial outcomes. ${ }^{97}$ Discovery is particularly necessary because, at the outset of many disputes, one party may have the bulk of relevant information while the other party lacks such information. ${ }^{98}$ When a private dispute resolution system limits discovery, it limits a device that otherwise serves to equalize the parties' relative positions. "To the extent that the private system's inquiry is less thorough, the private system permits the underlying power of the stronger party to persist undeflected."99 Even systems without a "discovery" process have alternate mechanisms to compel the revelation of information, and international arbitration can force the parties to produce relevant documents or face adverse inferences. The UDRP lacks

94 A. Michael Froomkin, Comments on ICANN Uniform Dispute Policy (1999), at http://www.law.miami.edu/ amf/icann-udp.htm.

${ }^{95}$ Nat'l Arbitration Forum, supra note $28, \S 6$.

96 Until October 15, 2001, NAF also had a supplemental rule regarding replies that could be used to respondent's disadvantage. Both parties were allowed to file a request for permission to file a reply containing new matter (and pay $\$ 250$ just to file the request), and both replies were given the same deadline (five days from when the response was due or submitted, whichever is earlier). If the complainant submits this supplemental filing on the last possible day, respondent had no opportunity to respond to the new allegations or documents. Under the revised rule, however, parties have an additional five days to respond to their opponents' replies. Id. $\$ 7$.

97 See Hickman v. Taylor, 329 U.S. 495 (1947) (discussing value and purpose of discovery).

98 Elizabeth G. Thornburg, Sanctifying Secrecy: The Mythology of the Corporate Attorney-Client Privilege, 69 Notre Dame L. Rev. 157, 203 (1993).

99 Bryant G. Garth, Privatization and the New Market for Disputes: A Framework for Analysis and a Preliminary Assessment, in 12 Studies in Law, Pol.tics, And Society 367, 382 (Susan S. Sibley \& Austin Sarat eds., 1992). 
even this. Nor has it been interpreted as a summary judgment-like proceeding in which the complainant loses in the event of any factual dispute.

Arbitrators, under the ICANN dispute resolution system, base their decisions on a complaint from the trademark owner and, in the absence of default, a response from the domain name registrant. Each side is only able to submit information and attach documents to which it already has access. Although theoretically the arbitrator can request further statements or documents, the arbitrator can only request documents that she knows about. Such action seems highly unlikely when the decision must be rendered in fourteen days. Consequently, the process leaves the complainant with no method of learning more about the respondent's intent or use of the domain name. It leaves the respondent with no method of learning more about the trademark owner's right to the mark. This lack of discovery or other disclosure device might be relatively insignificant in the clear cases of cybersquatting for which the UDRP was designed. It is more problematic in genuinely contested cases and cases in which the complainant is relying on a common law right rather than a registered trademark. It would also be cause for concern if the UDRP process were adopted for consumer disputes, defamation cases, fraud cases, antitrust cases, invasion of privacy cases, personal injury cases, or the like. Certainly, adding procedures requiring more information sharing to the process will add costs in terms of time and money, but it will also add to the overall fairness of an ODR process. ${ }^{100}$

\section{Lack of Meaningful Hearings}

The UDRP also uses a "hearing" process that is a poor model for any dispute that involves contested facts, especially contested facts not embodied in pre-existing documents. The ICANN arbitrator reads the parties' pleadings and attached documents and makes a decision. The pleadings are not even made under oath, but rather under an assertion of good faith similar to a federal court Rule 11 assertion. ${ }^{101}$ The Policy does not provide any penalty for making false statements in the complaint or response. ${ }^{102}$

Similarly, there is no adequate system to allow the fact finder to consider the kinds of information needed to resolve disputed facts. Under the ICANN dispute resolution procedure, any kind of hearing would be highly unusual. The Rules virtually prohibit even video conferences, tele-

100 Cf. Timothy J. Heinsz, The Revised Uniform Arbitration Act: Modernizing, Revising, and Clarifying Arbitration Law, 2001 J. DisP. Resol. 1, 46-50 (2001) (discussing the need to balance the policies favoring prehearing discovery and avoidance of expense and delay).

101 FED. R. Crv. P. 11.

102 ICANN Rules, supra note 16 , $\S 3$ (b) (xiv) and 5 (b)(viii). One filing a complaint in bad faith could be branded as a reverse domain name hijacker, but the only penalty is the bad publicity for being so categorized. 
phone conferences, and web conferences. ${ }^{103}$ Instead of hearing witnesses, the arbitrator makes her decision based on written submissions and accompanying documents. This is fast, but not helpful. Even WIPO has conceded that the process could be inadequate for more fact-intensive domain name disputes. ${ }^{104}$ The procedure would prove completely inadequate should the arbitrator need to decide whether a product was defective, a statement libelous, or a market monopolized if an ICANNlike procedure were used to resolve other types of Internet disputes. Also, when disputes involve decisions about the amount of damages, not the case in the ICANN process, ${ }^{105}$ an additional layer of factual disputes may require resolution.

Any dispute resolution system that applies law to fact, including a system that is operated online, needs to find ways to deal fairly with factual disputes. For example, credibility issues may be difficult to resolve without demeanor evidence or cross-examination, and some disputes may require the arbitrator to examine tangible evidence. ${ }^{106}$ " $[\mathrm{T}]$ hought needs to be given to the means through which the average [claimant] may submit evidence to the mechanism (certainly not ruling out ordinary mail) and how a mechanism may obtain credible testimony from witnesses (including how and when electronic 'witnesses' may be questioned)."107

Even in the limited context of domain name disputes, arbitrators have noted the impact of the UDRP when credibility issues are involved. Responding to a complainant's request to cross-examine respondent's evidence in order to establish bad faith, the panel responded that a matter requiring this kind of credibility check would be better resolved in "a forum, like a United States court, that permits for a more probing, searing search for the truth. This proceeding is not conducive to such credibility determinations given the lack of discovery and, in the normal course, the lack of live testimony." 108 The limitations on the presentation

103 Id. $\$ 13$.

104 WIPO, The Recognition of Rights, supra note 27, II 318(iii).

105 UDRP, supra note $16, \S 4$ (i) (only award will be cancellation or transfer of the domain name).

106 Council of Better Business Bureaus, supra note 47, at 14, http:// www.bbbonline.org/about/press/whitepaper.doc. See also Kornfeld, supra note 58, at 1 ("[The UDRP's] truncated nature may not be suitable for relatively complex cases involving a variety of claims and factual assertions .... [T] he process includes no testimony, cross-examination, briefing, or argument . . . The UDRP has no mechanism for evidentiary review; therefore facts, such as trademark rights, may be merely alleged.").

107 Council of Better Business Bureaus, supra note 47, at 14, http:// www.bbbonline.org/about/press/whitepaper.doc.

108 Document Tech. v. Int'l Elec. Communications, Case No. D2000-0270 (WIPO June 2, 2000) (Bernstein, Panelist), at http://arbiter.wipo.int/ domains/decisions (also refusing to consider complainant's supplemental filing). In that situation, the panel correctly ruled that the complainant had not met its burden of proof. The complainant remains free to file an action under the ACPA in federal court, once again attempting to acquire the domain name. However, the same problem could 
of evidence make it inadequate even for the cases into which the UDRP has evolved ${ }^{109}$ and certainly for most types of internet disputes.

\section{Unimaginative Use of Technology and ADR Methods}

The UDRP also makes very unimaginative use of existing technology. Even today, distant parties need not be confined to asynchronous written communication. Video conferencing, or the exchange of video files, would be a way to supply the fact finder with oral and nonverbal information missing from a purely written communication. Depending on the needs of the process, video technologies could be used synchronously or asynchronously. While it could not completely replace in person, face-toface encounters, it could provide an improvement over a single exchange of email.110 If written cross-examination would suffice, web-based communication methods such as chat rooms or instant messaging would offer real-time options.

The UDRP also ignores many existing ADR methodologies. If ODR were to be applied in other areas, looking only to stripped-down arbitration neglects numerous richer options. For example, mediators are actively involved in developing the standards and skills needed to adapt to the online environment, and a mediated resolution could, in some situations, provide a more satisfying solution to all parties. ${ }^{111}$ Other techniques, such as early neutral evaluation or mediated settlement conferences, may also be useful in the online setting.

\section{Decisionmaker Bias}

Whatever method of resolving disputes is chosen, the ICANN process also demonstrates the bias that can creep into the arbitral process. Procedural fairness requires that the decisionmaker be neutral. ${ }^{12}$ Among other things, this requires that the tribunal not have a personal interest in

arise in cases in which respondents challenge the credibility of complainant's assertions. If arbitrators nevertheless take the assertions on face value and find that complainants have met their burden of proof, the respondent will have been harmed through deprivation of an important process right; it will have lost the domain name through the UDRP without the opportunity to test the credibility of complainant's assertions.

${ }^{109}$ If ICANN adopted and enforced a rule that any material factual dispute required a ruling for respondent, thereby forcing disputed cases out of the UDRP and into the courts, the lack of a meaningful hearing would be less of a problem in the domain name context.

110 Frank A. Cona, Focus on Cyberlaw: Application of Online Systems in Alternative Dispute Resolution, 45 Buff. L. Rev. 972, 992 (1997); but see Joel B. Eisen, Are We Ready for Mediation in Cyberspace, 1998 B.Y.U. L. REv. 1305, 1335-40 (1998) (pointing out that use of technology can be a barrier to those who cannot afford it).

111 See Colin Rule, New Mediator Capabilities in Online Dispute Resolution, at http://www.mediate.com/articles/rule.cfm (last visited Nov. 11, 2001) (on file with the Journal of Small and Emerging Business Law); see generally KATSH \& RIFKIN, supra note 87.

112 Goldberg v. Kelly, 397 U.S. 254, 271 (1970). 
the outcome. ${ }^{113}$ It also requires that the decisionmaker be unbiased. Sometimes bias is direct: the arbitrator has, for example, a prior relationship with one of the parties or a financial stake in the dispute. ${ }^{114}$ This kind of bias is often prohibited by the tribunal's rules. Other times bias is indirect, growing out of "such subtle heuristics as cultural and professional biases." 115 A system in which one of the parties chooses the arbitration provider may involve a subtle kind of direct bias. Responsible providers of arbitral services probably have codes of ethics requiring arbitrators to disclose any direct conflicts of interest such as prior representation of a party, a financial stake in the outcome, or family relationship to a party. In the UDRP setting, however, this kind of direct bias arises from the volume of business that a repeat player can bestow. ${ }^{116}$ " $[\mathrm{I}] \mathrm{n}$ this era of entrepreneurial ADR, the arbitrator often does have a subtle but substantial economic interest in the outcome of the case in that his or her ability to get future cases depends, at least in part, on party satisfaction." 117 In the ICANN context, it is the trademark holders who are capable of bringing numerous cases to the arbitrator. ${ }^{118}$ As long as the DRPs are "dependent on getting their fees from Complainants, and thus have an interest in keeping Complainants happy, we are in danger of having a biased system."119

113 Tumey v. Ohio, 273 U.S. 510 (1927) (finding due process violation when judge compensated from proceeds of fines).

114 Reuben, supra note 55, at 1058.

115 Id.

116 Garth, supra note 99, at 382 ("If decision makers depend on a certain clientele for their business, and that clientele has a particular perspective or longstanding practice, we should not be surprised if that perspective or practice is not challenged."). For a helpful general discussion of the relationship between repeat player status and arbitral bias, see generally Lisa B. Bingham, On Repeat Players, Adhesive Contracts, and the Use of Statistics in Judicial Review of Employment Arbitration Awards, 29 McGeorge L. Rev. 223 (1998); Lisa B. Bingham, Employment Arbitration: The Repeat Player Effect, 1 EMP. RTs. \& EMP. Pol'y J. 189 (1997); Alan Scott Rau, Integrity in Private Judging, 38 S. Tex. L. Rev. 485 (1999).

117 Reuben, supra note 55, at 1063.

118 See A. Michael Froomkin, Comments on WIPO DNS RFC3, at http:// wipo2.wipo.int/process2/rfc/rfc3/comments/docs/wipo2.html ("Since complainants choose the arbitral body, the current system creates a financial incentive for arbitral bodies to compete to be "complainant friendly'.) (on file with the Journal of Small and Emerging Business Law); Helfer \& Dinwoodie, supra note 19 , at 211 (discussing incentives to be perceived as pro-complainant). In arbitration generally, Trial Lawyers for Public Justice, for example, alleges that the National Arbitration Forum markets its arbitration services as providing a defense for financial services companies against lawsuits from their consumers, and that MCI has a very close financial relationship with its mandatory arbitration service provider. Trial Lawyers for Public Justice, supra note 89 , at 8-9, http://ftc.gov/bcp/ altdisresolution/comments/landjr.pdt.

$119 \mathrm{King}$, supra note 74, at 501 . In some cases, the portion of the filing fee that goes to the provider rather than the arbitrator is a significant one. Compare CPR Institute FOR DisPute REsolution, supra note 28, para. 13 (single panelist, 1-2 domain names, $\$ 1000$ to Panelist and $\$ 1000$ to CPR) with ERESOLUTION, supra note 30 
Indirect bias is harder to pin down. Arbitrators, unlike conventional judges, are often valued for their substantive expertise in the subject area. Expertise is considered to be a positive factor, but it comes with a flip side: with expertise can come bias. For example, $89 \%$ of the arbitrators in the securities industry have been shown to be white males with an average age of sixty, many of whom spent their professional careers in the brokerage industry. ${ }^{120}$ It would not be surprising if former brokers were more likely to sympathize with the broker's side of the dispute. In health care arbitration, it would not be surprising if doctor-arbitrators were more likely to sympathize with the doctor's side of the dispute. ${ }^{121}$

Is indirect bias a problem in the implementation of the UDRP? It seems likely. Information about the identity and backgrounds of the arbitrators participating in the ICANN cases is available online. ${ }^{122}$ Reading the biographical sketches, it appears that most of the UDRP arbitrators are practicing intellectual property attorneys. As Professors Helfer and Dinwoodie note:

It is at least an open question whether decisionmakers from the private sector can sufficiently distance themselves from the milieu in which they practice to self-limit their own powers and develop balanced norms for the trademark-domain name interface. This is particularly true if panelists are permitted to trade on their UDRP expertise by representing trademark owners in future domain name disputes. ${ }^{23}$

Nothing in the rules bars a person from representing parties in some UDRP proceedings and serving as panelists in others. This is therefore an institution in which a person can serve as both judge and advocate. For example, in the ICANN proceeding concerning the domain name "bancochile.com," the Chilean bank was represented by Marino Porzio, who is best known for his decision as the UDRP arbitrator who awarded the domain name "barcelona.com" to the municipal government of Barcelona, Spain, taking it away from the operator of a Web portal for the

(single panelist, 1-2 domain names, $\$ 1000$ to panelist and $\$ 250$ to eRes). Statistics about forum shopping by complainants substantiate these concerns. See supra text accompanying notes 87-90.

120 U.S. Gen. Accounting OfFice, Employment Discrimination: How Registered Representatives Fare in Discrimination Disputes 2 (1994).

121 For an argument that such bias is a price worth paying to get expertise, see Stephen J. Ware, Arbitration and Unconscionability After Doctor's Associates, Inc. $v$. Casarotto, 31 WAKe Forest L. Rev. 1001, 1021-22 (1996).

122 Information about approved panelists is located on each DRP's website. See CPR Specialized Panels, at http://www.cpradr.org/speclpan_domainname.htm (last visited Nov. 8, 2001); eRESOLUTION, at http://www.eresolution.ca/services/dnd/ arbitrators.htm (last updated Oct. 24, 2001); National Arbitration Forum, at http:// www.arbforum.com/ about/arbitrators.asp (last visited Feb. 7, 2002); WIPO Domain Name Panelists, at http://www.arbiter.wipo.int/domains/panel/panelists.html (last modified Nov. 8, 2001).

123 Helfer \& Dinwoodie, supra note 19, at 212. 
city. ${ }^{124}$ Despite the absence of conscious animus, it is likely that arbitrators bring to the UDRP process their pre-existing attitudes toward the manipulable policy. ${ }^{125}$ The perspective through which the decision maker views a case can affect both the results in individual cases and the long-term interpretation and application of the UDRP.

Given these inevitable biases, the ICANN Policy fails in another important way. Each DRP lists a number of approved arbitrators, but there is no information about how particular individuals are assigned to particular cases, particularly those involving only one arbitrator. ${ }^{126}$ In those cases, the parties have no input into the assignment of the arbitrator. Except in cases of the most obvious and improper kind of bias, it is unlikely a party could successfully challenge a panelist. Each DRP has its own procedural rules regarding challenges. ${ }^{127}$ The grounds upon which a challenge can be brought also vary. For example, NAF sets forth specific grounds for disqualification. ${ }^{128}$ None would preclude an arbitrator with known attitudes about the meaning of controversial UDRP provisions from deciding a case. Nor is there a system for allowing parties, after a proceeding is over, to register complaints about a particular decisionmaker. ${ }^{129}$

Professor Geist has recently completed a study of the assignment of arbitrators to cases by the various DRPs in the first 3,000 ICANN decisions. This study reached a troubling conclusion: the identity of the arbitrators is the most important factor in determining case outcomes, and "case allocation appears to be heavily biased toward ensuring that a majority of cases are steered toward complainant-friendly panelists."130 Nor does it seem that arbitrator allocation is random. Some arbitrators

124 See Banco de Chile v. Bord, Case No. D2001-0695 (WIPO Aug. 14, 2001) (Limbury, Panelist), at www.arbiter.wipo.int/domains/decisions.

125 Cf. Ellen E. Deason, Court-Appointed Expert Witnesses: Scientific Positivism Meets Bias and Deference, 77 Or. L. Rev. 59, 98-100 (1998); Bernard L. Diamond, The Fallacy of the Impartial Expert, 3 ARCHIVE CRIM. Psychodynamics 221 (1959) (both contending that expertise is not neutral).

${ }^{126}$ It is even more important that arbitrators whose decisions are virtually unreviewable be unbiased than that judges be so. This is particularly true when the arbitration is in effect a process "devised by insiders to be imposed on outsiders." Katherine Van Wetzel Stone, Rustic Justice: Community and Coercion under the Federal Arbitration Act, 77 N.C. L. REv. 931, 1017 (1999).

127 For example, although WIPO has no specific rule, it notes that it does its own check as to "whether there are any facts or circumstances, past or present, or that could arise in the foreseeable future, that might call into question that person's independence in the eyes of one or both of the parties." WIPO SuPPLEMENTAL Rules, $\$ 8$ Annex C. NAF allows five days from appointment to challenge an arbitrator. NAT'L ARBITRATION FORUM, supra note $28, \S 10$ (d).

128 Nat'l ARbirration Forum, supra note $28, \S 10(\mathrm{~b})$ (listing personal bias concerning a party, prior representation of a party, direct financial interest, and relationship within the third degree to a party or attorney).

129 Kornfeld, supra note 58, at 9.

130 Geist, Fair.com, supra note 89 , at 8. 
on the approved list are never chosen. ${ }^{131}$ Others serve frequently. For example, despite a roster of 131 panelists, $53 \%$ of all single arbitrator cases at the National Arbitration Forum (512 of 966 cases) were decided by only 6 people, and complainants won $94 \%$ of those cases. ${ }^{132}$ There may be innocent explanations for this pattern. But, as noted above, DRPs do have significant financial incentives to develop a reputation of being complainant-friendly so long as complainants alone choose where to file their cases.

Only in three-member panels do the parties have any control over assignment of arbitrators. In these situations, each party chooses one arbitrator, providing a better chance that at least one member of the panel will share that party's approach to the law. They also have the advantage of requiring discussion and consultation among the arbitrators, which should lead to a more thorough consideration of the issues raised by the case. ${ }^{133}$ In international commercial arbitration, use of a three-member panel is the accepted norm, and often a default rule if the parties fail to specify a different selection method. ${ }^{134}$ In UDRP cases involving threemember panels, complainants win about $60 \%$ of the time, as opposed to single-arbitrator cases, in which they win about $83 \%$ of the time. ${ }^{35}$ Excluding default cases, complainants win in three-member-panel cases only $45 \%$ of the time. ${ }^{136}$ These statistical disparities, along with accepted international practice, indicate that an ODR system that operates on an arbitration-like model and strives for fairness should adopt three-member panels, with party input into the choice of panelists. While this would increase costs, and might add to the time required for deliberation, the improvement in accuracy of individual cases and legitimacy of the process would offset the disadvantages.

131 For example, two arbitrators, both of whom are probably considered more friendly to respondents, have participated in three-member panels (chosen by respondents) but have never been chosen to be the single arbitrator, despite allegedly random assignments in 1,629 WIPO single-panel cases. Yet 104 arbitrators were selected 5 or more times by WIPO to decide single panel cases. Id. at 26.

${ }^{132} I d$. at 8. While the existence of default cases explains some of this result, it does not explain all. None of the other DRPs have similar statistics. For example, the 6 busiest panelists at WIPO decided $17.2 \%$ of the cases and the 6 busiest panelists at eResolution decided $17.3 \%$ of the cases. Id. at 25 .

133 Helfer \& Dinwoodie, supra note 19, at 194.

134 Id., citing Model Law on International Commercial Artitration, U.N. Commission on International Trade Law, 18th Sess., Art. 11(3), U.N. Doc. A/40/17, Annex 1 (1985), reprinted in 1985 U.N. Comm'n on Int'l Trade L. Y.B. 16, U.N. Sales No. E.87.V.4, available at http://www.uncitral.org/en-index.htm.

135 Geist, Fair.com, supra note 89, at 8. One might conclude from this data that respondents are the ones who usually opt for the three-member panel. Surprisingly, it is often the complainant who chooses the three-member option; they are responsible for about $62 \%$ of those panels. Professor Geist suggests that complainants are aware of the possibility of "inconsistent and poorly reasoned decisions" from a single arbitrator and choose more panelists to decrease the possibility of a wrong decision. Id. at 21.

136 Id. at 20. 
It is not likely that the arbitrators with pro-complainant records are purposely slanting their decisions toward trademark holders. Rather, they come to the process with certain attitudes toward trademarks and their role in the domain name system, and these attitudes predispose them to want to protect the plum of exclusive domain name rights for those whom they see as the most worthy owners. This is human and understandable, but it is unacceptable in a dispute resolution system that purports to be unbiased and fair.

\section{No Review Mechanism}

UDRP arbitrators have rendered decisions that are inconsistent in their interpretation of the substantive requirements and in their implementation of the procedural rules. Because the process contains no internal appeal process, there is no way to challenge any of these decisions, either to correct the result in an individual case or to reconcile splits in what is becoming the "law" of ICANN. ${ }^{137}$ There is no way to correct arbitrators who are creating bad "law" or those who believe that trademark holders should have broader rights than those included in the UDRP as written. ${ }^{138}$ "The result is rule by individual arbitrator rather than rule by a 'uniform' dispute resolution policy." 139 In ICANN's case, we are able to document these inconsistencies because UDRP decisions are available. Any ODR system looking to ICANN for lessons should heed the problem of decisionmaker discrepancies and consider a method for monitoring decisions and a realistic system of appeal.

\section{UNEQUAL POWER AND THE ROLE OF GOVERNMENTS}

Examining the UDRP from a distance also yields some more general lessons about the problems of creating privatized processes and the role that governments should play in their design and implementation. Any

137 Although theoretically a party disappointed with the result of the UDRP process can file a lawsuit to try to change the result, it is not an appeal but a de novo process. It is also likely to be characterized by the problems of cost and delay that the UDRP was adopted to prevent. There have been more than three thousand ICANN proceedings disposed of by decision, and only about twenty five lawsuits filed to challenge the result. While this could reflect total happiness with the process, it seems more likely that it is at least in part due to the unrealistically short deadline and the probable expense of the process. An internal appeal, particularly one in which the appellate panel was as balanced as possible, could add less cost for both parties and provide a more meaningful check on erroneous decisions. See also supra text accompanying note 94 for a discussion of the problems created by the short appeal deadline. See generally Helfer \& Dinwoodie, supra note 19, 225-30 (listing reasons that appeal to national courts is an inadequate check on UDRP decisions).

138 Neil J. Cohen, Forum: ICANN at the Crossroads, 1 InTERNet L. \& Bus. 583, 584 (2000). See also Kornfeld, supra note 58 (noting that some arbitrators were less than enthusiastic about free speech, gave generic names more protection than would U.S. trademark law, and failed to recognize bulk registration as a legitimate business).

${ }^{139}$ Cohen, supra note 138 , at 584 . 
system that aspires to be fair must keep in mind the comparative power of the participants, and must include a way to monitor and enforce at least minimum standards.

Some Internet theory harkens back to the Net's early days as a relatively homogeneous band of fellow scientists and computer geeks. It posits that the rules of the Internet should be established through selfregulation that arises through the practices of the Internet community. ${ }^{140}$ With the addition of major commercial activity, the ideological hostility to government intervention shared by early Internet enthusiasts has now been bolstered by the free market vision of the commercial users. This law created by contract is alleged to be both more efficient and more fair than whatever a traditional government might require. ${ }^{141}$

The ICANN experience, as well as the contracts of adhesion beginning to be used in e-commerce transactions, causes the concept of the Internet as a "community" of users regulating only themselves to collapse when commercial interests are at stake. As Professor Lemley notes: " $[\mathrm{N}]$ orms often operate among peers. If the society is divided into different groups-say, one group that always sells and another group that always buys-their desires and expectations from interaction may be so different that informal agreement is unlikely." 142 In analyzing the priva-

140 David R. Johnson, Industry $\mathcal{E}^{\circ}$ Government Have Swapped Traditional Roles of Advocacy and Oversight in Shaping Internet Policy, Legal Times, Oct. 12, 1998, at 28; David G. Post \& David R. Johnson, Chaos Prevailing on Every Continent: Towards a New Theory of Decentralized Decision-Making in Complex Systems, 73 CHI.-KeNT L. REv. 1055, 1086-88 (1998). Such theorists often refer to desirable Net ordering as "bottom-up," a term coined by Freidrich Hayek and referring to "the laissez-faire network of promises among individuals, the growing-up of customary norms" (good) as opposed to "top-down" law laid down by the state (bad). See Margaret Jane Radin \& R. Polk Wagner, The Myth of Private Ordering: Rediscovering Legal Realism in Cyberspace, $73 \mathrm{CH}$.KENT L. REV. 1295, 1297 (1998).

141 David R. Johnson \& David Post, Law and Borders-The Rise of Law in Cyberspace, 48 STAN. L. REV. 1367 (1996) (arguing that the architecture of cyberspace precludes notice of governing law that is crucial to law's legitimacy, and "spillover" effects lead to application of the law of a nation with no right to govern a particular transaction). See also Neil Weinstock Netanel, Cyberspace Self-Governance: A Skeptical View from Liberal Democratic Theory, 88 CAL. L. REv. 395, 401 (2000) (noting that for supporters of cyberspace self-government,

cyberspace is partly a model and partly a metaphor for a fundamental restructuring of our political institutions. Cyberians view cyberspace as a realm in which 'bottom-up private ordering' can and, indeed, should supplant rule by the distant, sluggish, and unresponsive bureaucratic state. By its very architecture and global reach, they contend, cyberspace will ultimately elude the strictures of statecreated law, challenging the efficacy and theoretical underpinnings of the territorial sovereign state.)

142 Mark A. Lemley, The Law and Economics of Internet Norms, 73 Chi.-Kent L. Rev. 1257, 1273 (1998). See also Julie E. Cohen, Copyright and the Jurisprudence of Self-Help, 13 BERKELEY TECH. L.J. 1089, 1123 (1998) (Applied to the consumer mass market, "the notion that commercial law should be premised on market norms is deeply problematic. ... Norms presuppose communities, and . . . the community that drives the evolution of mass-market norms is the community of providers.") 
tized processes, we should abandon the fiction that these systems evolve naturally from the shared values of equally influential parties. ${ }^{143}$

Depending on the context, it is likely that the interests of small and emerging businesses are aligned with consumers on these issues. When dealing with larger, more powerful businesses (such as when serving as a supplier or franchisee), small businesses may find themselves on the receiving end of a contract of adhesion. They may also find themselves unprotected by traditional consumer law. ${ }^{144}$ Notice, for example, that when the American Arbitration Association proudly announced the adoption of B2B dispute-resolution guidelines, they did so with the backing of Microsoft, AT\&T, and FedEx Corp. ${ }^{145}$ These guidelines stress speed and cost savings and promise only ambiguous platitudes:

We believe that all businesses are entitled to a fundamentally fair dispute management process that includes access to neutral dispute resolution providers. ... We encourage the use of a variety of cost-effective methods to resolve disputes at the earliest possible stage. ... We support the use of appropriate technology to aid the swift and economical management of disputes. ${ }^{146}$

Is a party entitled to a lawyer, to discovery, to a live hearing, to crossexamine witnesses, to a written decision, to appeal the decision, to choose litigation instead? Must it pay exorbitant filing fees? Can it be forced to give up its right to a jury trial before a dispute has even arisen? None of these issues are addressed.

Further, in the absence of some kind of reliable certification program for B2C disputes, customers may choose to buy from large realworld businesses rather than an intriguing small but unknown company, especially one located in another country. In a world free of standards or accountability for ADR programs, a consumer may easily choose the large company with a local "real world" store rather than risk a dispute with a small and distant Internet merchant. This diminishes the choices of consumers and diminishes the Internet's democratizing ability to let smaller sellers reach a larger market.

149 See Edward Brunet, Toward Changing Models of Securities Arbitration, 62 BRook. L. REv. 1459, 1475-76 (1996).

144 Small businesses are also likely to be disadvantaged in the ICANN process itself. For example, a small enterprise may have difficulty meeting the twenty-day response deadline, may not be able to afford a lawyer to represent it in the UDRP proceeding, and also may not be able to afford an expensive lawsuit to challenge an adverse UDRP decision.

145 Graig Stedman, Arbitration Group Proposes B2B Dispute-Resolution Guidelines, COMPUTERWORLD, Jan. 4, 2001, at http://www.computerworld .com/storyba/ 0,4125,NAV47_STO55850,00.html (on file with The Journal of Small and Emerging Business Law).

146 Am. Arbitration Ass'n, eCommerce Dispute Management Protocol: Principles for Managing Business-to-Business Relationships, http:// www.adr.org/ index2.1.jsp?JSPssid=10838 (last visited Mar. 17, 2002). 
These power disparities also illustrate that even technologically accessible processes may not function equitably unless the system provides some kind of representative for the weaker party. Many respondents may have defaulted because they are unable to cope with drafting a legalistic answer, complete with supporting documents, on twenty-days' notice. They may not be able to decipher the shifting burdens of proof regarding legitimate interests and bad faith registration and use. ${ }^{147}$ In this case and others, the ODR provider or other group should supply the one-shot player with some assistance. This could take the form of a lawyer, an ombudsperson, a user group, or a facilitator, so long as the assistant is competent and has not been co-opted by the more powerful party. ${ }^{148}$ The change to the online environment does not eliminate the need for advice about legal and procedural rights ${ }^{149}$ or the need for help in fully presenting a party's factual position. If disputants have the right to request particular arbitrators or mediators, an ombudsperson could knowledgeably advise them. The need to use sophisticated ODR technology may in fact create an additional need for help, if only to assist a party with the computer equipment or skills needed to participate. In a multinational setting, a representative may also be needed to help deal with the problems in communication generated by language and cultural gaps. ${ }^{150}$ In short, an ombudsperson has the potential to become a kind of repeat player in the particular dispute resolution process and thereby help make the process operate more evenhandedly.

People drafting rules and standards should also be honest about the decisions they are making about risk. Often you can shift risk, but you cannot eliminate it. The desire for the privatized processes arises largely out of the uncertainty created by differing national laws. The solutions do not negate the risk-they shift it. In the case of the UDRP as it is being interpreted, it shifts risk from trademark holder to domain name holder, including those small businesses trying to establish an identity on the

147 Respondents are less likely than complainants to be assisted by lawyers even when they do respond. Webster, supra note 17, at 227.

148 See Ethan Katsh, The Online Ombuds Office: Adapting Dispute Resolution to Cyberspace, at http://www.mediate.com/articles/katsh/cfm (last visited Nov. 12, 2001) (explaining role of ombudsperson generally and online) (on file with The Journal of Small and Emerging Business Law); Schneider \& Kuner, supra note 86, at 26, 32-33 (suggesting collective action through user groups or a facilitator to handle disputes).

${ }_{149}$ Yes, I know, theoretically ADR isn't about rights but about interests. But a party cannot evaluate her options, including whether to assert possible rights, without knowing what relief the conventional legal system might or might not provide. And, ICANN's version of ADR is still an adversarial process that is theoretically applying legal rules.

150 Nora Femenia, ODR and the Global Management of Customers' Complaints: How Can ODR Techniques Be Responsive to Different Social and Cultural Environments? (Dec. 12, 2000), at http://www.mediate.com/ articles/femenia.cfm (paper originally presented at the Joint Conference of the OECD, HCOPIL, and ICC at the Hague). 
Internet. ${ }^{151}$ In the e-commerce context, arbitration clauses can shift too much risk from the merchant to the consumer. In doing so, they shift risk to the party whose understanding of the transaction is already crippled by market failure. ${ }^{152}$ This is not only unfair, but also counterproductive. A dispute resolution system that shifts risk can decrease the incentive that a resourceful party might have to find better ways to decrease that risk. For example, sophisticated search engines can significantly decrease a business's need to have a particular domain name in order for Internet users to locate its particular web site; given sufficient incentive, the technology to search for particular companies will be devised. If sellers wanted potential customers to be able to compare customer service/dispute resolution systems, they would advertise them, and shopping "bots" would be created that could search for warranty and ADR terms as well as for price and physical features. If knowledge of the law is the problem, some enterprising multinational accounting firm would create (and sell access to) a database with relevant information. If being subjected to the courts and laws of too many countries is unacceptable, technologies that allow an Internet actor to target or de-target particular areas will be perfected as a way to decrease the risk. ${ }^{153}$ These developments may happen in any case, as arbitration systems shift risk imperfectly, but they might happen faster if greater incentive remains on the party with the resources and the expertise to find a better solution.

Government still needs to play a role in the world of otherwise private dispute resolution. First, national or international bodies should set minimum standards for ADR due process. ${ }^{154}$ These dispute resolution systems are performing public functions, and asking public courts to

151 Mueller, supra note 88, at 25 ("Start-ups need to be able to establish a presence and an identity. It is wrong to make challenges to domain name registrations too easy, and it is unwise to tilt dispute resolution criteria too far toward protection of existing trademarks.")

152 John Rothchild, Protecting the Digital Consumer: The Limits of Cyberspace Utopianism, 74 IND. L.J. 893, 943 (1999); Gibbons, supra note 15, at 793; Brunet, supra note 143 , at 1464 .

153 This last technology is already emerging, although the main impetus seems to come from those entities wishing to engage in regulatory arbitrage (conducting a business - such as online gambling - that would be illegal in certain states or countries) or to do targeted advertising (finding customers most likely to purchase the seller's goods). See generally Matt Richtel, High Stakes in the Race to Invent a BetterBlocker, N.Y. Times, June 28, 2001, http://www.nytimes.com/2001/06/28/ technology/28GAMB.html; Stefanie Olsen, Yahoo Ads Close in on Visitors' Locale, CNETNEws.com, June 27, 2001, at http://news.cnet.com/news/0-1005-2006397360.html (reporting that Yahoo signed a deal to send consumers specific online ads based on where they live or work) (on file with the Journal of Small and Emerging Business Law); Michael Geist, E-borders Loom, for Better or Worse, Globe \& MAIL, June 28, 2001, at http://news.globetechnology.com/servlet/ GAMAArticleHTML.

154 It may be that international consensus on ODR due process would be as elusive as international consensus on substantive law. For a discussion of the issue by the Australian government, see Consumer Affarrs Drvision, supra note 9, at 23, http:/ /www.ecommerce.treasury.gov.au. 
enforce contract terms and arbitration results. Governments should refuse to do so (and thus should refuse to stay litigation, enforce arbitral awards, or give preclusive effect to arbitral awards) unless those processes ensure an acceptable level of procedural fairness. Second, governments (and the public) should have access to information about the nature and results of the private complaints. When information about recurring problems goes from the public domain (courts) to the private (ODR), enforcement agencies and other advocacy groups lose valuable information needed to monitor and enforce existing laws. ${ }^{155}$ "If the general production of . . . information [about the activities of private entities] diminishes significantly, there will of course be much less basis for public critique and regulation-indeed, little basis even for an informed public deference to business self-governance." 156 Third, since unregulated private processes have the power to vary substantive law by contract, governments should also insist on certain mandatory laws that cannot be contractually waived. ${ }^{157}$ When government fora lose control over disputes, they lose a large amount of control over the law. This is particularly true in a country like the United States in which much of the implementation and enforcement of legal norms is left to private litigation. The trend in Internet disputing to move disputes out of the courts and into private processes, if unregulated, will not only change the litigants' own process rights, but also effectively change the substantive law.

Government intervention may also be required to underwrite or monitor any kind of private system adopted as a method for encouraging acceptable standards for ODR. One method that has been suggested to provide consumers with more reliable information about a merchant's dispute resolution methods is the creation of private trustmark systems. ${ }^{158}$ In order to be entitled to display the trustmark, the company would have to adhere to agreed minimum standards in its dispute resolution procedures. Failure to do so could lead to censure or loss of the

155 See, e.g., Daniel Eisenberg, Anatomy of a Recall, Time, Sept. 11, 2000, at 29 (describing how litigation regarding Firestone ATX tires became feasible only after plaintiffs' lawyers secured discovery regarding consumer complaints and other lawsuits, and judge allowed sharing of the information with lawyers involved in similar suits).

156 Garth, supra note 99, at 386. See also Menkel-Meadow, supra note 15, at 46 (suggesting data collection to identify patterns of problems).

${ }_{157}$ For example, Germany's highest civil court ruled that Microsoft cannot prevent dealers from unbundling the software and selling it separately. This appears to enforce traditional first sale rights despite Microsoft's desire to interpret the transaction as a license that limits future uses. See Rick Perera, German Court Says OK to Unbundling, INFOWORLD.COM, July 7, 2000, at http://www.infoworld.com/articles. Following this decision, prices for various Windows programs decreased $20-30 \%$ as a secondary market developed. John Lettice, German Court Ruling Triggers 30\% Price Cut on Windows, Register, Sep. 5, 2000, at http://www.theregister.co.uk/content/ archive/1/12985.html.

158 Task Force on E-Commerce \& Alternative Dispute Resolution, supra note 59, at 5-12, http://www.law.washington.edu/ABA-eADR/drafts/2001 .05.21 draft. 
mark. However, the difficulties of online enforcement (and the ease of counterfeiting online graphics) may mean that the trustmark-sponsoring organizations will seek aid in monitoring compliance or soliciting consumer complaints.

In addition, since the trustmark providers will themselves be private groups, some entity-like a government agency-will need to monitor the provider to see that the alleged standards are acceptable and are being enforced. ${ }^{159}$ If the standards required for the award of the trustmark are inadequate, the government should withhold any kind of enforcement or participation. Further, the operation of the UDRP demonstrates that there can be flaws in an ODR system both as it appears on paper and in the way that system is implemented. Trustmarks, presumably, would be granted based on an analysis of a company's written policy. ${ }^{160}$ Even this step should require intense scrutiny. The rules, as they would operate in context, need to be fair and not just facially parallel. ${ }^{161}$ Then, the trustmark holders would need to be monitored by the trustmark-granting entity to assure that the holders apply their ODR procedures in compliance with their written standards. ${ }^{162}$ The government, in turn, could monitor those who award trustmarks to be sure that the public receives meaningful protection rather than just a pretty symbol on a web page.

In order to ensure procedural fairness, governments may also need to underwrite at least some of the cost of ODR systems. A private system costs money, and someone has to pay for it. Yet to put a high price tag on participation runs contrary to the goal of creating a process that is accessible and affordable, even for small disputes. It is not surprising that the Better Business Bureau has suggested that the expense of effective sys-

159 The Task Force suggests that the standards might arise out of the "ODR Provider community" itself. Id. at 7. Given the extremely minimal requirements proposed by the "Electronic Commerce and Consumer Protection Group," it is hard to generate a lot of optimism about how rigorous industry-sponsored trustmark standards would be. See Brian Krebs, Groups Embrace E-commerce Dispute Resolution Plan, NEwSBYTES, June 7, 2000, at http://www.computeruser.com/news $/ 00 / 06 / 07 /$ news 13 . html. Note that the "consumer protection group" consists of America Online, AT\&T, Dell Computer Corporation, IBM, Microsoft, Network Solutions, Time Warner Inc., and VISA U.S.A. Inc. The actual proposals are available online. Elec. Commerce \& Consumer Protection Group, Guidelines for Merchant-to-Consumer TransacTIONS AND COMMENTARY, at http://www.ecommercegroup.org/guidelines.htm (last visited Nov. 13, 2001).

${ }^{160}$ It might easily be less direct than that. A company would acquire a trustmark based on its promise to refer disputes to some designated ODR provider, under that ODR provider's rules.

161 See, e.g., the discussion of the differential impact of various UDRP procedures, supra text accompanying notes 94-96.

162 The ABA Task force noted the problem of "what entity will monitor the actions of third party ODR Providers that are offering services to the public." TASK Force on E-Commerce \& Alternative Dispute Resolution, supra note 59, at 6, http://www.law.washington.edu/ABA-eADR/drafts/ 2001.05.21draft.html. 
tems will require "a partnership among governments, nonprofit foundations, academic institutions and the private sector" to ensure the technological infrastructure will be created. ${ }^{163}$ It is also not surprising that the ABA Task Force studying e-commerce has tentatively raised the issue of the need for a government subsidy. ${ }^{164}$ Governments, of course, pay for the real court system and may be less than enthusiastic about underwriting ODR processes when they already pay for courts. On the other hand, it may take funding from an outside source to de-link the ability to choose the dispute resolution provider and the potential bias of the decision makers. ${ }^{165}$

Governments may instead put their resources into adapting the ability of existing court structures to deal with disputes quickly and efficiently. It would be a mistake to assume the real world courts will not adopt some of the more effective technologies available if it will save money or generate convenience. The U.S. federal courts, for example, have already made a great deal of information available online through their PACER system. ${ }^{166}$ Courts hold conferences and even oral arguments by teleconference to save attorneys the time and expense of traveling to the courthouse. ${ }^{167}$ Telephonic and videotape depositions are already here, as are electronic filing and electronic briefs. ${ }^{168}$ The trial of the future may bear little resemblance to the single-event, in-person norm of today. ${ }^{169}$ Some states may create special court systems to handle

163 Council of Better Business Bureaus, supra note 47 , at 13 , http:// www.bbbonline.org/about/press/whitepaper.doc. In addition to the technology costs, arbitrators and mediators need to be paid. It is noteworthy that within the first year of its operation, the fees charged by the DRPs under the ICANN process had already increased dramatically. King, supra note 74, at 503. WIPO's panelists, for example, receive $\$ 1,000$ to decide a case involving one or two domain names, and all they generally need do is read the paperwork and write an opinion. This already far exceeds the amount in controversy in many consumer disputes. Resolving disputes that are longer and more fact-intensive would likely require even higher fees.

164 Task force on E-Commerce \& Alternative Dispute Resolution, supra note 59, at 10, http://www.law.washington.edu/ABA-ADR/drafts/2001 .05.21draft.

165 Cf. King, supra note 74, at 501 .

([A]s long as the providers are dependent on getting their fees from Complainants, and thus have an interest in keeping Complainants happy, we are in danger of having a biased system. While it would not be fair to require the respondent to pay the fees, ICANN should try to develop a system under which the Complainants are not the sole source of money for the Providers.).

166 Directory of Electronic Public Access Services to Automated Information in the United States Federal Courts, at http://pacer.psc .uscourts.gov/pubaccess.html.

167 See, e.g., 8TH TEX. App. (EL PASO) Loc. R. 39.4, http://www.8thcoa .courts.state.tx.us/Rules.pdf. Lawyers who lack in-house teleconferencing equipment have participated in oral argument through support systems available at Kinko's. Conversation between Beth Thornburg and Chief Justice David Chew, Apr. 19, 2001.

168 Gordon Bermant, Courting the Virtual: Federal Courts in an Age of Complete InterConnectedness, 25 Oніо N.U. L. REv. 527, 543 (1999) (appellate briefs being filed in CD-ROM format).

169 Paul D. Carrington, Virtual Civil Litigation: A Visit to John Bunyan's Celestial City, 98 Colum. L. Rev. 1516 (1998). 
e-commerce or other Internet disputes. ${ }^{170}$ Courts are also adopting time standards that are intended to limit the period from case filing to final disposition. ${ }^{171}$

Those searching for uniformity through ODR must also be aware that individual governments will not necessarily yield their role in lawmaking just because a private system is in place. For example, the state of California decided to provide even greater protection to the performers of the future wanting their own names as domain names. It therefore passed (unanimously) its own statute protecting personal names, despite the UDRP and despite the laws of other states and nations. ${ }^{172}$ National courts can also be expected to apply existing laws to Internet disputes. ${ }^{173}$ Other states or nations may refuse to compel arbitration, whether online or otherwise, and may allow lawsuits to proceed despite the existence of arbitration clauses. No system can provide protection from divergent standards unless everyone defers to it.

\section{CONCLUSION}

The problems of differing legal standards, choice of law, personal jurisdiction, and enforcement of judgments in global interactions are real, and are not going away. ODR does not solve them, but it could provide a Band-Aid until a better solution comes along. Well-designed ADR systems will always play a role if they are a truly consensual alternative to formal court structures. Private systems, however, are only useful if the applicable law is legitimate and the applicable procedures are actually fair.

170 Pam Belluck, Michigan Plans a High-Tech Lure, N.Y. Times, Feb. 22, 2001, at A10 (reporting that to lure tech companies to Michigan, its governor wants to establish a separate "cybercourt" for cases involving technology and high-tech businesses, a court in which virtually everything would be done via computer rather than in a courtroom).

171 See, e.g., Tex. R. Crv. Pro. 190 (discovery control plans); Tex. R. Crv. Pro. $165 a$ (allowing cases to be dismissed for want of prosecution if they fail to comply with time standards contained in Rules of Judicial Administration). Unfortunately, governments also fail to provide sufficient funding to staff the court system so that it is capable of disposing of the cases within the mandated deadlines.

172 See Lynda Gledhill, New Law on Cyber Piracy, S.F. Gate, Aug. 23, 2000, at http:/ /www.sfgate.com/cgi-bin/article.cgi?file $=/$ chronicle/archive (describing new statute that includes protection of "promising newcomers who may not meet federal 'sufficiently famous' standards but whose names might be pirated" and making it bad faith just to register the name, with no "use" required). The California law also creates a remedy of restitution and a fine as well as transfer of the domain name. See also David McGuire, California Passes Sweeping Anti-Cybersquatting Law, Newsbytes, Aug. 23, 2000, at http://www.newsbytes.com/pubNews/00/154103.html (questioning whether state courts provide the best venue to resolve disputes over globally available domain names).

173 See, e.g., Dinwoodie, supra note 66, at 508 n.43 (citing cases from China, France, Germany, India, and the United Kingdom applying unfair competition law to domain name disputes). 
Unfortunately, in settings involving power imbalances, the systems designed to date have not met the due process sniff test. Acceptable rules could be geared toward providing affordable access to the process, notice, a method for sharing relevant information, a reliable way of resolving factual disputes, the use of truly unbiased decision makers, process transparency, written reasoned opinions, and some kind of meaningful appeal. The system would balance cost and fairness in ways that impact parties evenly. It would not be mandatory, but rather would have to attract parties who were not compelled to participate.

Government, too, will need to stay engaged in the ODR debate. Private law adopted globally suffers from a lack of legitimacy; one must ask whether the entity attempting to impose rules has any right to do so. Many types of disputes are simply not suitable for a privatized resolution, especially a nonconsensual one. They involve too many issues of important public policies, often policies that affect people other than the immediate disputants, to allow a private group to choose the rule they like best and make it the "law." Also, public interests that balance private property and contract rights under real world governments (including free speech, an intellectual commons, and consumer protection) must not be eliminated from these privatized systems. Neither voluntary industry self-regulation nor ad hoc case law developments will be enough to assure that important values are protected in Internet dispute resolution.

The prohibition of private processes would also leave parties unprotected. In the context of small dollar disputes in cross-border transactions, the public court systems provide an inadequate solution. Nevertheless, private dispute resolution must be both substantively and procedurally just. An ODR system that stacks the deck is only an improvement in public relations, not in access to justice. Rather than repeat platitudes about the "unique qualities of the Internet," 174 we must face its impact on the real world before blessing a process to settle its disputes.

174 White House, A Framework for Global Electronic Commerce 3 (July 1, 1997), at http://www.ecommerce.gov/framewrk.htm. 